\title{
Review
}

\section{Epidural Steroids in the Management of Chronic Spinal Pain: A Systematic Review}

\author{
Salahadin Abdi, MD', PhD, Sukdeb Datta, MD², Andrea M. Trescot, MD³, David M. Schultz, MD, Rajive \\ Adlaka, MD', Sairam L. Atluri, MD', Howard S. Smith, MD, PhD', and Laxmaiah Manchikanti, MD
}

From: ${ }^{1}$ University of Miami, Miller School of Medicine, Miami, FL;

2Vanderbilt University School of Medicine, Nashville, TN; 3University of Florida, Gainesville, FL; 4University of Minnesota Medical School, Minneapolis, MN; ${ }^{\text {Pain }}$ Control Associates, Munster, IN; ${ }^{\circ}$ Tristate Pain Management, Loveland, $\mathrm{OH}$; ${ }^{7}$ Albany Medical College, Albany, NY; and ${ }^{8}$ Pain Management Center of Paducah, $\mathrm{KY}$; and University of Louisville, $\mathrm{KY}$. Dr. Abdi' is Professor and Chief, Division of Pain Medicine, Department of Anesthesiology, Perioperative Medicine and Pain Management, University of Miami, Miller School of Medicine, Miami, FL; Dr. Datta ${ }^{2}$ is Assistant Professor, Department of Anesthesiology, Vanderbilt University School of Medicine, and Director, Pain Management Services VA Tennessee Valley Healthcare System, Nashville, TN.

Dr. Trescot ${ }^{3}$ is Director, Pain Fellowship Program, University of Florida, and The Pain Center, Orange Park, FL. Dr. Schultz ${ }^{4}$ is Assistant Professor, Department of Anesthesiology, University of Minnesota Medical School and Medical Director MAPS Medical Pain Clinics, Minneapolis, MN. Dr. Adlaka ${ }^{5}$ is Medical Director, Pain Control Associates, Munster, IN. Dr. Atluri ${ }^{6}$, Tristate Pain Management, Loveland, OH. Dr. Smith ${ }^{7}$ is Academic Director of Pain Management, Professor of Anesthesiology, Albany Medical College, Albany, NY. Dr. Manchikanti is Medical Director, Pain Management Center of Paducah, KY; and Associate

Clinical Professor of Anesthesiology and Perioperative Medicine, University of Louisville, KY.

Address Correspondence: Salahadin Abdi, MD, PhD, Department

of Anesthesiology, Perioperative

Medicine, and Pain Management,

University of Miami, Miller School of

Medicine, 1611 NW 12th Ave., SW 303,

Miami, FL 33136

E-mail: sabdi@med.miami.edu

Funding: None.

Conflict of Interest: None.

Free full manuscript:

www.painphysicianjournal.com
Background: Epidural injection of corticosteroids is one of the most commonly used interventions in managing chronic spinal pain. However, there has been a lack of well-designed randomized, controlled studies to determine the effectiveness of epidural injections. Consequently, debate continues as to the value of epidural steroid injections in managing spinal pain.

Objective: To evaluate the effect of various types of epidural steroid injections (interlaminar, transforaminal, and caudal), in managing various types of chronic spinal pain (axial and radicular) in the neck and low back regions.

Study Design: A systematic review utilizing the criteria established by the Agency for Healthcare Research and Quality (AHRQ) for evaluation of randomized and non-randomized trials, and criteria of Cochrane Musculoskeletal Review Group for randomized trials were used.

Methods: Data sources included relevant English literature performed by a librarian experienced in Evidence Based Medicine (EBM), as well as manual searches of bibliographies of known primary and review articles and abstracts from scientific meetings within the last 2 years. Three reviewers independently assessed the trials for the quality of their methods. Subgroup analyses were performed among trials with different control groups, with different techniques of epidural injections (interlaminar, transforaminal, and caudal), with different injection sites (cervical/thoracic, lumbar/sacral), and with timing of outcome measurement (short- and long-term).

Outcome Measures: The primary outcome measure is pain relief. Other outcome measures were functional improvement, improvement of psychological status, and return to work. Short-term improvement is defined as 6 weeks or less, and long-term relief is defined as 6 weeks or longer.

Results: In managing lumbar radicular pain with interlaminar lumbar epidural steroid injections, the evidence is strong for short-term relief and limited for long-term relief. In managing cervical radiculopathy with cervical interlaminar epidural steroid injections, the evidence is moderate. The evidence for lumbar transforaminal epidural steroid injections in managing lumbar radicular pain is strong for short-term and moderate for long-term relief. The evidence for cervical transforaminal epidural steroid injections in managing cervical nerve root pain is moderate. The evidence is moderate in managing lumbar radicular pain in post lumbar laminectomy syndrome. The evidence for caudal epidural steroid injections is strong for short-term relief and moderate for long-term relief, in managing chronic pain of lumbar radiculopathy and postlumbar laminectomy syndrome.

Conclusion: There is moderate evidence for interlaminar epidurals in the cervical spine and limited evidence in the lumbar spine for long-term relief. The evidence for cervical and lumbar transforaminal epidural steroid injections is moderate for long-term improvement in managing nerve root pain. The evidence for caudal epidural steroid injections is moderate for long-term relief in managing nerve root pain and chronic low back pain.

Key words: Spinal pain, low back pain, cervicalgia, epidural steroids, interlaminar, caudal, transforaminal, radiculopathy, axial pain, postlaminectomy syndrome, failed back surgery syndrome.

Pain Physician 2007; 10:185-212 
E pidural injections for managing chronic pain are one of the most commonly performed interventions in the United States $(1,2)$. Utilization statistics in the Medicare population of epidural procedures showed an increase from 802,735 in 1998 to $1,776,153$ in 2005 , or $121 \%$ over a period of 7 years. The projected statistics in the total U.S. population is expected to be 4 times the procedures performed in the Medicare population. Multiple systematic reviews (3-14), a meta-analysis (15), multiple guidelines (16-19), health technology assessments by insurers, and local medical review policies and coverage decisions have been published. However, controversy continues regarding the effectiveness of epidural steroid injections. They have been used to treat radicular pain from herniated discs, spinal stenosis, and chemical discs and axial spinal pain. The evidence is highly variable based on the reviewer and the evidence has been rated from indeterminate to strong in various publications. In addition, 3 types of epidurals, namely interlaminar, transforaminal, and caudal; and administration in 3 separate regions namely lumbar, cervical, and thoracic, with variable results complicate the picture of practice of interventional pain management.

Spinal pain is the most common of all chronic pain disorders. The lifetime prevalence of spinal pain has been reported as $54 \%$ to $80 \%$ (20-32). Annual prevalence of chronic low back pain ranges from $15 \%$ to $45 \%(22,23,25,30)$. Studies of the prevalence of low back pain and neck pain $(23,25)$ and impact on general health showed $25 \%$ of patients reporting Grade II to Grade IV low back pain (high pain intensity with disability), whereas it was $14 \%$ in patients with neck pain. Modern evidence has shown that chronic persistent low back pain and neck pain in children, adults, and elderly are seen in up to $25 \%$ to $60 \%$ of patients, one year or longer after the initial episode (33-47). In addition, spinal pain is also associated with enormous economic, societal, and health impact (48-65). There are not any interventions which provide definite and long-term improvement in chronic low back pain, neither conservative nor surgical (66-76). Further, postlaminectomy syndrome and other symptoms, such as postsurgery syndrome, representing a cluster of syndromes wherein the expectations of the patient and the spine surgeon are not met, following spine surgery are common phenomena with persistent pain following spine surgery (77-83).

Nevertheless, the benefit and most effective route of administration for epidural steroids remain controversial. Several approaches are available to access the lumbar epidural space; namely, interlaminar, transforaminal, and caudal $(3,4,16-19,84,85)$. There are substantial differences among these 3 approaches. The interlaminar entry can be directed more closely to the assumed site of pathology, requiring less volume than the caudal route. The transforaminal approach is target-specific and requires the smallest volume to reach the primary site of pathology; specifically, the anterior-lateral epidural space as well as the dorsal root ganglion. On the other hand, the caudal entry is relatively easily achieved with minimal risk of inadvertent dural puncture, but requires a relatively high volume $(10-20 \mathrm{~mL})$ of injectate to reach the site of pathology.

The underlying mechanism of action of epidurally administered steroid and local anesthetic injections is still not well understood. It is believed that the achieved neural blockade alters or interrupts nociceptive input, reflex mechanisms of the afferent fibers, self-sustaining activity of the neurons, and the pattern of central neuronal activities. Further, it is believed that local anesthetics interrupt the pain-spasm cycle and reverberating nociceptor transmission. On the other hand, corticosteroids reduce inflammation by inhibiting either the synthesis or release of a number of pro-inflammatory mediators and by causing a reversible local anesthetic effect (86-94).

The purpose of this review is to evaluate and update the effects of various types of epidural injections (interlaminar, transforaminal, and caudal) in the management of various types of chronic spinal pain (axial and radicular, cervical and lumbar). Several important studies and complications have been reported since the previous systematic review (3).

\section{Methods}

\section{Literature Search}

The literature search included using a professional librarian from an academic medical center (Vanderbilt University Medical School, Nashville, TN) utilizing PubMed, EMBASE, and ISI Web of Science (January 1966-October 2006); systematic reviews; narrative reviews; cross-references to the reviews; various published trials; and peer-reviewed abstracts from scientific meetings during the past 2 years, published in the English language. The search strategy including the MeSH terms was performed by the librarian. Results from all 3 databases were combined and duplicates were removed. PubMed strategies included a keyword search of non- 
Medline citations to retrieve in-process and supplied by publisher citations. All articles were reviewed by at least 3 authors in the group and results were scored as a mean of the 3 scores rounded up to a whole number. Table 1 in the Systematic Review of Diagnostic Utility of Selective Nerve Root Blocks in this issue of the journal illustrates search strategies utilized.

\section{Selection Criteria}

The review focused on randomized and non-randomized evaluations, and reports of complications. The population of interest was patients suffering with chronic spinal pain for at least 3 months. Three techniques of epidural injections (interlaminar, transforaminal, and caudal) with local anesthetic, steroid, or other drugs provided for management of spinal pain were evaluated. All the studies providing appropriate management with outcome evaluations of 3 months or longer and statistical evaluations were reviewed. The primary outcome measure was pain relief at various points in time. The secondary outcome measures were functional or psychological improvement, return to work, and complications.

For evaluating the quality of individual articles, we have used the criteria from the Agency for Healthcare Research and Quality (AHRQ) publication (95). For evaluation of randomized trials, criteria described by Cochrane Review Group for musculoskeletal disorders (96) also have been utilized.

For studies to be included, an algorithmic criterion should have been met and a study should have answered positive questions (at least partially) in all 3 categories $(3,4,18,19,97,98)$. If a study had 10 or more randomized trials meeting inclusion criteria, no observational studies were included. AHRQ criteria, Cochrane Review Group criteria, and algorithmic criteria of inclusion and exclusion are shown in multiple publications $(3,4,18,19,95-98)$ and also in this issue of the journal in the systematic review of percutaneous adhesiolysis.

\section{Analysis of Evidence}

Qualitative analysis was conducted, using 5 levels of evidence for effectiveness of epidural steroids as illustrated in Table 1. Pain relief was evaluated on both a short-term (< 6 weeks) and long-term ( 6 weeks or longer) basis. A study was judged to be positive if the authors concluded that the epidural steroid injection therapy was more effective than the reference treatment in randomized trials or simply concluded that it was effective. All other conclusions were considered negative. If, in the opinion of reviewers, there was conflict with the conclusion, the conclusions were changed with appropriate explanations.

Table 1. Designation of levels of evidence.

\begin{tabular}{|l|l||}
\hline Level I & $\begin{array}{l}\text { Conclusive: Research-based evidence with multiple relevant and high-quality scientific studies or consistent reviews } \\
\text { of meta-analyses. }\end{array}$ \\
\hline Level II & $\begin{array}{l}\text { Strong: Research-based evidence from at least 1 properly designed randomized, controlled trial; or research-based } \\
\text { evidence from multiple properly designed studies of smaller size; or multiple low quality trials. }\end{array}$ \\
\hline Level III & $\begin{array}{l}\text { Moderate: } \\
\text { a) Evidence obtained from well-designed pseudorandomized controlled trials (alternate allocation or some other } \\
\text { method); } \\
\text { b) Evidence obtained from comparative studies with concurrent controls and allocation not randomized (cohort } \\
\text { studies, case-controlled studies, or interrupted time series with a control group); } \\
\text { c) Evidence obtained from comparative studies with historical control, 2 or more single-arm studies, or interrupted } \\
\text { time series without a parallel control group. }\end{array}$ \\
\hline Level IV & $\begin{array}{l}\text { Limited: Evidence from well-designed, nonexperimental studies from more than 1 center or research group; or } \\
\text { conflicting evidence with inconsistent findings in multiple trials. }\end{array}$ \\
\hline Level V & $\begin{array}{l}\text { Indeterminate: Opinions of respected authorities, based on clinical evidence, descriptive studies, or reports of expert } \\
\text { committees. }\end{array}$ \\
\hline
\end{tabular}

Adapted from ref 3, 16, 17, 95, 97, 98. 


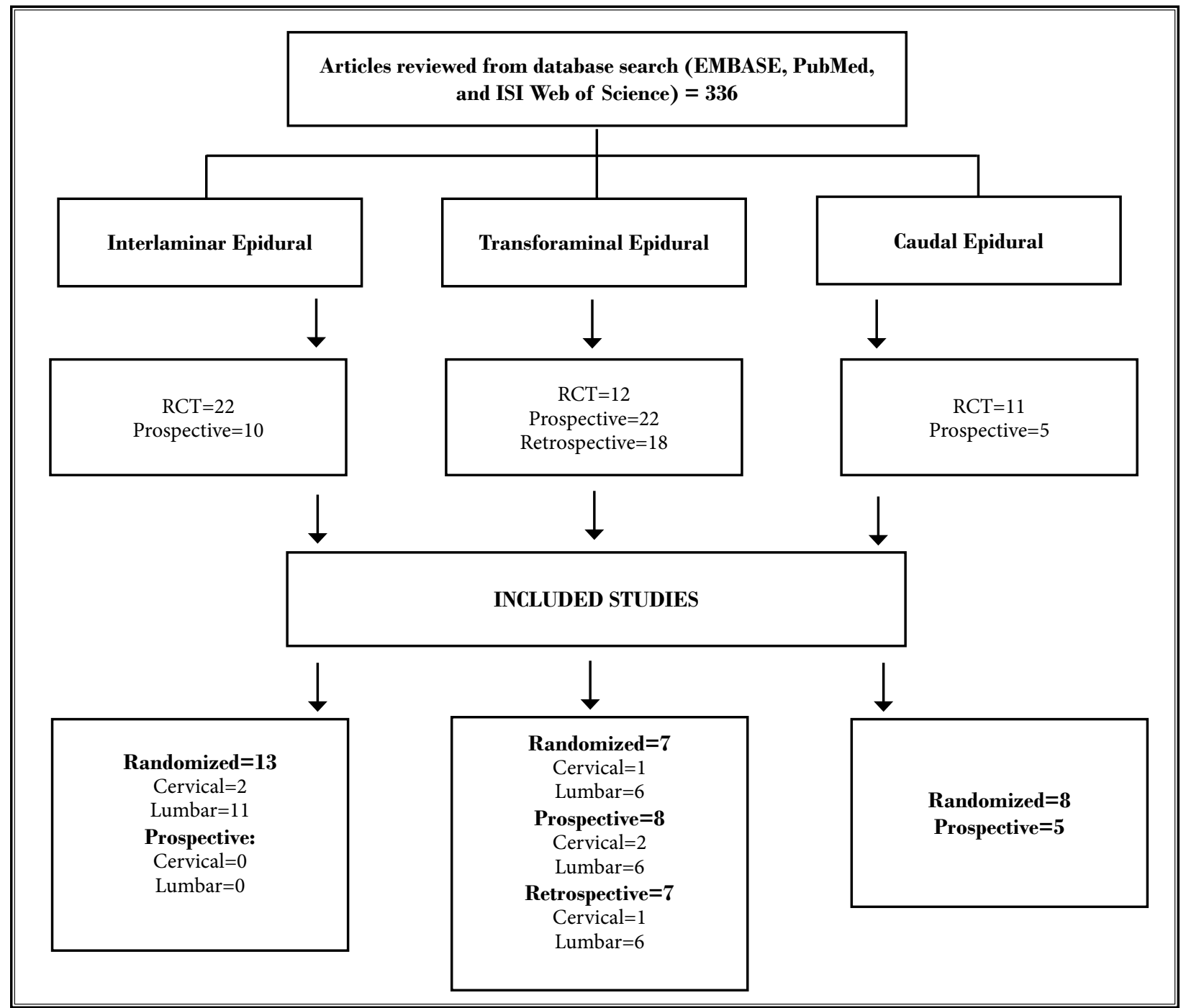

Fig. 1. Systematic review flow chart.

\section{Results}

The literature search was carried out as described in the methods section. Fig. 1 shows a systematic review flow chart with number of total articles reviewed and included in each category of interlaminar, transforaminal, and caudal epidurals with itemization into randomized, prospective, and retrospective.

\section{Interlaminar Epidural Injections}

Our search strategy yielded multiple studies evaluating the effectiveness of interlaminar epidural injections. These included 22 randomized or doubleblind trials (99-120), 9 non-randomized prospective trials (121-129), and multiple other observational trials (130-161).

\section{Methodological Criteria}

Of the 22 randomized trials, 13 studies met inclusion criteria $(99-103,107-109,113,116,117,119,120)$. One study (104) was excluded as they studied effects of subarachnoid and epidural midazolam. Two studies $(110,111)$ focused on diabetic polyneuropathy and intractable postherpetic neuralgia. One study (114) evaluated only inpatients, whereas 4 evaluations $(105,106,115,118)$ failed to evaluate long-term relief. One study (112) was not included due to lack of data for review. Tables 2 and 3 illustrate various characteristics and results of published randomized trials meeting inclusion criteria. Eleven lumbar trials $(99,100-103$, $107,108,116,117,119,120)$ and 2 cervical trials $(109,113)$ were included. 
Epidural Steroids in the Management of Chronic Spinal Pain

Table 2. Characteristics of published randomized trials of lumbar interlaminar epidural injections.

\begin{tabular}{|c|c|c|c|c|c|}
\hline Study/Methods & Participants & Intervention(s) & Outcome(s) & Result(s) & $\begin{array}{c}\text { Conclusion(s) } \\
\text { Short-term } \\
\text { relief }<6 \mathrm{wks} \\
\text { Long-term } \\
\text { relief }>6 \mathrm{wks}\end{array}$ \\
\hline $\begin{array}{l}\text { Wilson-McDonald et } \\
\text { al (119) } \\
\text { Randomized, } \\
\text { controlled trial } \\
\text { AHRQ score: } 10 / 10 \\
\text { Cochrane score: } 7 / 10\end{array}$ & $\begin{array}{l}93 \text { pts with MRI } \\
\text { evidence of a disc } \\
\text { prolapse, spinal sten- } \\
\text { osis, or a combination. } \\
\text { Pts had lumbosacral } \\
\text { nerve root pain which } \\
\text { had not resolved within } \\
6 \text { wks minimum. }\end{array}$ & $\begin{array}{l}\text { Experimental: epidural } \\
\text { injection of bupivacaine } \\
0.5 \%(40 \mathrm{mg}) \text { with } \\
\text { methylprednisone } 80 \mathrm{mg} \text {. } \\
\text { Control: intramuscular } \\
\text { injection of } 0.5 \% \text { ( } 40 \\
\text { mg) bupivacaine with } 80 \\
\text { mg methylprednisone. }\end{array}$ & $\begin{array}{l}\text { Timing: } 6 \\
\text { wks, } 24 \text { mos. } \\
\text { Outcome } \\
\text { measures: } \\
\text { Oswestry } \\
\text { Disability index, } \\
\text { pain relief. }\end{array}$ & $\begin{array}{l}\text { In the first } 5 \text { wks } \\
\text { after epidural } \\
\text { injection a useful } \\
\text { improvement } \\
\text { in nerve root } \\
\text { symptoms was } \\
\text { seen. }\end{array}$ & $\begin{array}{l}\text { Positive short- } \\
\text { term and } \\
\text { negative long- } \\
\text { term relief }\end{array}$ \\
\hline $\begin{array}{l}\text { Arden et al (120) } \\
\text { Double-blind, } \\
\text { randomized placebo } \\
\text { controlled: TRIM } \\
\text { AHRQ score: } 10 / 10 \\
\text { Cochrane score: } 9 / 10\end{array}$ & $\begin{array}{l}228 \text { pts with unilateral } \\
\text { sciatica. }\end{array}$ & $\begin{array}{l}\text { Experimental: } \\
\text { triamcinolone } 80 \mathrm{mg} \\
\text { and } 10 \mathrm{ml} \text { of } 0.25 \% \\
\text { bupivacaine } \\
\text { Control: interspinous } \\
\text { injection with } 2 \mathrm{~mL} \text { of } \\
\text { normal saline. }\end{array}$ & $\begin{array}{l}\text { Timing: } 3,6, \\
\text { 12, 26, and } 52 \\
\text { weeks. Outcome } \\
\text { measures: } \\
\text { Oswestry } \\
\text { disability index, } \\
\text { Likert scale, SF- } \\
\text { 36, VAS. }\end{array}$ & $\begin{array}{l}\text { Lumbar epidural } \\
\text { steroid injection } \\
\text { produced a } \\
\text { statistically significant } \\
\text { improvement in } \\
\text { function over placebo } \\
\text { in } 3 \text { wks. By } 6 \text { wks, } \\
\text { benefit lost. }\end{array}$ & $\begin{array}{l}\text { Positive short- } \\
\text { term and } \\
\text { negative long- } \\
\text { term relief }\end{array}$ \\
\hline $\begin{array}{l}\text { Carette et al (100) } \\
\text { Randomized, double- } \\
\text { blind trial } \\
\text { AHRQ score: } 10 / 10 \\
\text { Cochrane score: } 10 / 10\end{array}$ & $\begin{array}{l}158 \text { pts with sciatica } \\
\text { due to a herniated } \\
\text { nucleus pulposus. } \\
\text { Treatment group: } 78 \\
\text { Placebo group: } 80 .\end{array}$ & $\begin{array}{l}\text { Experimental: } \\
\text { methylprednisolone } \\
\text { acetate ( } 80 \mathrm{mg} \text { and } 8 \\
\mathrm{~mL} \text { of isotonic saline) } \\
\text { Control: isotonic saline } \\
1 \mathrm{~mL} \\
\text { Frequency: } 3 \text { epidural } \\
\text { injections } 3 \text { wks apart. }\end{array}$ & $\begin{array}{l}\text { Timing: } 6 \text { wks, } \\
3 \text { mos, } 12 \text { mos } \\
\text { Outcome } \\
\text { measures: need } \\
\text { for surgery } \\
\text { Oswestry } \\
\text { Disability } \\
\text { scores. }\end{array}$ & $\begin{array}{l}\text { Significant } \\
\text { improvement } \\
\text { was seen in } \\
\text { leg pain in the } \\
\text { methylprednisolone } \\
\text { group after } 6 \text { weeks, } \\
\text { with no difference } \\
\text { after } 3 \text { and } 12 \text { mos. }\end{array}$ & $\begin{array}{l}\text { Positive short- } \\
\text { term and } \\
\text { negative long- } \\
\text { term relief }\end{array}$ \\
\hline $\begin{array}{l}\text { McGregor et al (99) } \\
\text { Randomized, } \\
\text { controlled trial } \\
\text { AHRQ score: } 6 / 10 \\
\text { Cochrane score: } 5 / 10\end{array}$ & $\begin{array}{l}44 \text { pts with low back } \\
\text { and leg pain. }\end{array}$ & $\begin{array}{l}\text { Caudal epidural vs } \\
\text { lumbar epidural. }\end{array}$ & $\begin{array}{l}\text { Visual analog } \\
\text { scale. }\end{array}$ & $\begin{array}{l}\text { No significant } \\
\text { improvement. }\end{array}$ & $\begin{array}{l}\text { Negative short- } \\
\text { term and long- } \\
\text { term relief }\end{array}$ \\
\hline $\begin{array}{l}\text { Pirbudak et al (117) } \\
\text { Randomized non- } \\
\text { blinded trial } \\
\text { AHRQ score: } 7 / 9 \\
\text { Cochrane score: } 6 / 10\end{array}$ & $\begin{array}{l}92 \text { pts with sciatica. } \\
\text { Experimental } \\
\text { with steroids and } \\
\text { amitriptyline: } 46 . \\
\text { Control with } \\
\text { benzylprednisolone } \\
\text { and bupivacaine } \\
\text { steroids: } 46 .\end{array}$ & $\begin{array}{l}\text { Experimental: } \\
\text { benzylprednisolone } \\
(14 \mathrm{mg})+\text { bupivacaine } \\
\text { and } 10-50 \mathrm{mg} \text { oral } \\
\text { amitriptyline. }\end{array}$ & $\begin{array}{l}\text { Timing: } 2 \text { wks, } \\
6 \text { wks, and } 9 \\
\text { mos. Outcome } \\
\text { measures: VAS } \\
\text { and Oswestry } \\
\text { low back pain } \\
\text { disability } \\
\text { questionnaire. }\end{array}$ & $\begin{array}{l}\text { Lumbar epidural } \\
\text { steroid injection } \\
\text { reported pain } \\
\text { relief up to } 6 \text { mos. } \\
\text { Additional oral } \\
\text { amitriptyline } \\
\text { increased pain } \\
\text { relief to } 9 \text { mos. }\end{array}$ & $\begin{array}{l}\text { Positive short- } \\
\text { term and long- } \\
\text { term relief }\end{array}$ \\
\hline $\begin{array}{l}\text { Snoek et al (101) } \\
\text { Randomized trial } \\
\text { AHRQ score: } 7 / 10 \\
\text { Cochrane score: } 6 / 10\end{array}$ & $\begin{array}{l}51 \text { pts with lumbar } \\
\text { root compression } \\
\text { documented by } \\
\text { neurological deficit } \\
\text { and a concordant } \\
\text { abnormality noted } \\
\text { on myelography. } \\
\text { Experimental: } 27 \\
\text { Control: } 24 \text {. }\end{array}$ & $\begin{array}{l}\text { Experimental: } 80 \mathrm{mg} \\
\text { of methylprednisolone } \\
(2 \mathrm{~mL}) . \\
\text { Control: } 2 \mathrm{~mL} \text { of normal } \\
\text { saline } \\
\text { Frequency: single } \\
\text { injection. }\end{array}$ & $\begin{array}{l}\text { Timing: } 3 \text { days } \\
\text { and an average } \\
\text { of } 14 \text { mos. } \\
\text { Outcome } \\
\text { measures: } \\
\text { Pain, sciatic } \\
\text { nerve stretch } \\
\text { tolerance. }\end{array}$ & $\begin{array}{l}\text { No statistically } \\
\text { significant } \\
\text { differences were } \\
\text { noted in either } \\
\text { group. }\end{array}$ & $\begin{array}{l}\text { Negative short- } \\
\text { term and long- } \\
\text { term relief }\end{array}$ \\
\hline $\begin{array}{l}\text { Cuckler et al (102) } \\
\text { Randomized, double- } \\
\text { blind trial } \\
\text { AHRQ score: } 9 / 10 \\
\text { Cochrane score: } 9 / 10\end{array}$ & $\begin{array}{l}73 \text { pts with back pain } \\
\text { due to either acute } \\
\text { herniated nucleus } \\
\text { pulposus or spinal } \\
\text { stenosis of }>6 \text { mos. } \\
\text { Experimental: } 42 \\
\text { Control: } 3.1\end{array}$ & $\begin{array}{l}\text { Experimental: } \\
80 \mathrm{mg}(2 \mathrm{~mL}) \text { of } \\
\text { methylprednisolone }+5 \\
\mathrm{~mL} \text { of procaine } 1 \% . \\
\text { Control group: } 2 \\
\mathrm{~mL} \text { saline }+5 \mathrm{~mL} \text { of } \\
\text { procaine } 1 \% .\end{array}$ & $\begin{array}{l}\text { Timing: } 24 \text { hrs } \\
\text { and an average of } \\
20 \text { mos. Outcome } \\
\text { measures: } \\
\text { subjective } \\
\text { improvement, } \\
\text { need for surgery. }\end{array}$ & $\begin{array}{l}\text { There was no } \\
\text { significant short- } \\
\text { term or long-term } \\
\text { improvements } \\
\text { between both } \\
\text { groups. }\end{array}$ & $\begin{array}{l}\text { Negative short- } \\
\text { term and long- } \\
\text { term relief }\end{array}$ \\
\hline
\end{tabular}


Table 2. Continued. Characteristics of published randomized trials of lumbar interlaminar epidural injections.

\begin{tabular}{|c|c|c|c|c|c|}
\hline Study/Methods & Participants & Intervention(s) & Outcome(s) & Result(s) & $\begin{array}{c}\text { Conclusion(s) } \\
\text { Short-term } \\
\text { relief }<6 \mathrm{wks} \\
\text { Long-term } \\
\text { relief }>6 \mathrm{wks}\end{array}$ \\
\hline $\begin{array}{l}\text { Dilke et al (103) } \\
\text { Randomized trial } \\
\text { AHRQ score: } 7 / 10 \\
\text { Cochrane score: } 7 / 10\end{array}$ & $\begin{array}{l}100 \text { pts with low back } \\
\text { pain and sciatica of } \\
1 \text { week to more than } \\
2 \text { yrs. } \\
\text { Experimental: } 51 \\
\text { Control: } 48 .\end{array}$ & $\begin{array}{l}\text { Experimental group: } 10 \\
\mathrm{~mL} \text { of saline }+80 \mathrm{mg} \\
\text { of methylprednisolone. } \\
\text { Control group: } 1 \mathrm{~mL} \text { of } \\
\text { saline. }\end{array}$ & $\begin{array}{l}\text { Timing: } 2 \text { wks } \\
\text { and } 3 \text { mos. } \\
\text { Outcome } \\
\text { measures: pain } \\
\text { relief, analgesic } \\
\text { use, and } \\
\text { resuming work. }\end{array}$ & $\begin{array}{l}\text { Initial Improvement: } \\
60 \% \text { in the } \\
\text { treatment group and } \\
31 \% \text { in the control } \\
\text { group. A greater } \\
\text { proportion of } \\
\text { actively treated pts } \\
\text { improved at } 3 \text { mos. }\end{array}$ & $\begin{array}{l}\text { Positive short- } \\
\text { term and long- } \\
\text { term. relief }\end{array}$ \\
\hline $\begin{array}{l}\text { Ridley et al (107) } \\
\text { Randomized trial } \\
\text { AHRQ score: } 9 / 10 \\
\text { Cochrane score: } 8 / 10\end{array}$ & $\begin{array}{l}35 \text { pts with low back } \\
\text { pain and sciatica } \\
\text { of mean duration } \\
\text { approximately } 8 \text { mos. } \\
\text { Experimental: } 19 \\
\text { Control: } 16 .\end{array}$ & $\begin{array}{l}\text { Experimental: } 10 \mathrm{~mL} \\
\text { of saline }+80 \mathrm{mg} \text { of } \\
\text { methylprednisolone } \\
(\mathrm{n}=19) \text {. } \\
\text { Control: saline } 2 \mathrm{~mL} \text {, } \\
\text { interspinous ligament } \\
(\mathrm{n}=16) .\end{array}$ & $\begin{array}{l}\text { Timing: } 1 \text { wk, } 2 \\
\text { wks, } 3 \text { mos, and } \\
6 \text { mos. } \\
\text { Outcome } \\
\text { measures: } \\
\text { pain control } \\
\text { improvement } \\
\text { in straight leg } \\
\text { raising. }\end{array}$ & $\begin{array}{l}90 \% \text { of the pts in } \\
\text { the treated group } \\
\text { compared to } 19 \% \\
\text { in the control } \\
\text { group showed } \\
\text { improvement at } 1 \\
\text { wk, } 2 \text { wks, and } 12 \\
\text { wks. By } 24 \text { wks, } \\
\text { relief deteriorated } \\
\text { to pretreatment } \\
\text { levels. }\end{array}$ & $\begin{array}{l}\text { Positive short- } \\
\text { term and } \\
\text { negative long- } \\
\text { term relief }\end{array}$ \\
\hline $\begin{array}{l}\text { Rogers et al (108) } \\
\text { Randomized, single- } \\
\text { blind, sequential } \\
\text { analysis } \\
\text { AHRQ score: } 6 / 10 \\
\text { Cochrane score: } 5 / 10\end{array}$ & $\begin{array}{l}30 \text { pts with low back } \\
\text { pain. } \\
\text { Experimental = } 15 \\
\text { Control }=15 .\end{array}$ & $\begin{array}{l}\text { Experimental: local } \\
\text { anesthetic + steroid. } \\
\text { Control: local anesthetic } \\
\text { alone. }\end{array}$ & $\begin{array}{l}\text { Timing: } 1 \\
\text { month. } \\
\text { Outcome } \\
\text { measures: pain } \\
\text { relief and nerve } \\
\text { root tension } \\
\text { signs. }\end{array}$ & $\begin{array}{l}\text { Experimental } \\
\text { group had } \\
\text { significantly better } \\
\text { results. Long-term } \\
\text { results were similar } \\
\text { for both. }\end{array}$ & $\begin{array}{l}\text { Positive short- } \\
\text { term relief and } \\
\text { negative long- } \\
\text { term relief }\end{array}$ \\
\hline $\begin{array}{l}\text { Kraemer et al }(116) \\
\text { Randomized trial } \\
\text { AHRQ score: } 6 / 10 \\
\text { Cochrane score: } 5 / 10\end{array}$ & $\begin{array}{l}\text { Control: } 46 \\
\text { Intervention: } 40 .\end{array}$ & $\begin{array}{l}\text { Control: paravertebral } \\
\text { local injection of } \\
\text { local anesthetic, with } \\
\text { intramusclar steroid } \\
\text { injection. Intervention: } \\
\text { lumbar interlaminar } \\
\text { steroid injection. }\end{array}$ & $\begin{array}{l}\text { Timing: } 3 \text { wks } \\
\text { and } 3 \text { mos. } \\
\text { Outcome } \\
\text { measures: pain } \\
\text { relief. }\end{array}$ & $\begin{array}{l}\text { Epidural injections } \\
\text { were more effective } \\
\text { than paravertebral } \\
\text { injections. }\end{array}$ & $\begin{array}{l}\text { Positive short- } \\
\text { term and } \\
\text { negative long- } \\
\text { term relief }\end{array}$ \\
\hline
\end{tabular}

Since there were multiple randomized trials evaluating lumbar pain $(\mathrm{N}=1)$, no prospective or retrospective evaluations were considered for inclusion. The single prospective evaluation of the cervical spine (121) was not included as all the patients who underwent interlaminar epidural steroid injections also underwent transforaminal epidural steroid injections.

\section{Effectiveness}

Of the 11 randomized trials $(99,100-103,107,108$, $116,117,119,120)$ included in the evaluation of lumbar radiculitis, 7 were positive for short-term relief (100, $103,107,108,116,117,119)$, whereas only 2 studies were positive for long-term relief $(103,117)$.

In the evaluation of cervical pain and radiculopathy, 2 randomized trials $(109,113)$ were available. Both the randomized trials $(109,113)$ evaluating the effectiveness of interlaminar cervical epidural steroids in managing cervical radiculopathy were positive.

Of the 4 randomized trials, which were positive, Dilke et al (103) studied low back pain and sciatica, and Pirbudak (117) evaluated all patients with sciati$\mathrm{ca}$, whereas Castagnera et al (109) and Stav et al (113) studied chronic cervical radicular pain.

Among the studies reporting negative short-term and long-term results, patients with disc herniation, spinal stenosis, and postlumbar laminectomy syndrome with low back and/or sciatica were included. Description of Study Characteristics

Descriptive characteristics of various studies in- 
Epidural Steroids in the Management of Chronic Spinal Pain

Table 3. Characteristics of published randomized trials of cervical interlaminar epidural injections.

\begin{tabular}{|c|c|c|c|c|c|}
\hline Study/Methods & Participants & Intervention(s) & Outcome(s) & Result(s) & $\begin{array}{l}\text { Conclusion(s) } \\
\text { Short-term } \\
\text { relief }<6 \mathrm{wks} \\
\text { Long-term } \\
\text { relief }>6 \mathrm{wks}\end{array}$ \\
\hline $\begin{array}{l}\text { Castagnera et al (109) } \\
\text { Randomized trial } \\
\text { AHRQ score: } 7 / 10 \\
\text { Cochrane score: } 6 / 10\end{array}$ & $\begin{array}{l}14 \text { patients: local } \\
\text { anesthetic and } \\
\text { steroid. } \\
10 \text { patients: local } \\
\text { anesthetic, steroid } \\
\text { + morphine } \\
\text { sulfate. }\end{array}$ & $\begin{array}{l}\text { I. } 0.5 \% \text { lidocaine } \\
+ \text { triamcinolone } \\
\text { acetonide. } \\
\text { II. Local anesthetic } \\
+ \text { steroid }+2.5 \mathrm{mg} \text { of } \\
\text { morphine sulfate. }\end{array}$ & $\begin{array}{l}\text { Timing: } 1 \text { month, } 3 \\
\text { mos, and } 12 \text { mos. } \\
\text { Outcome measures: } \\
\text { pain relief. }\end{array}$ & $\begin{array}{l}\text { The success rate } \\
\text { was } 79 \% \text { vs. } 80 \% \text { in } \\
\text { group I and II. } \\
\text { Overall, initial } \\
\text { success rate was } \\
96 \%, 75 \% \text { at } 1 \\
\text { month, } 79 \% \text { at } 3 \\
\text { mos, } 6 \text { mos, and } 12 \\
\text { mos. }\end{array}$ & $\begin{array}{l}\text { Positive short- } \\
\text { term and long- } \\
\text { term relief }\end{array}$ \\
\hline $\begin{array}{l}\text { Stav et al (113) } \\
\text { Randomized trial } \\
\text { AHRQ score: } 6 / 10 \\
\text { Cochrane score: } 5 / 10\end{array}$ & $\begin{array}{l}\text { Experimental: } 25 \\
\text { patients. } \\
\text { Control: } 17 \\
\text { patients. }\end{array}$ & $\begin{array}{l}\text { Experimental: } \\
\text { epidural steroid and } \\
\text { lidocaine injections } \\
\text { Control: steroid and } \\
\text { lidocaine injections } \\
\text { into the posterior } \\
\text { neck muscles }\end{array}$ & $\begin{array}{l}\text { Timing: } 1 \text { week and } \\
1 \text { year. } \\
\text { Outcome measures: } \\
\text { pain relief, change } \\
\text { in range of motion, } \\
\text { reduction of daily } \\
\text { dose of analgesics, } \\
\text { return to work. }\end{array}$ & $\begin{array}{l}\text { One week } \\
\text { improvement 36\% } \\
\text { vs } 76 \% \text {; } \\
\text { One year } \\
\text { improvement } 12 \% \\
\text { vs } 68 \% \text {. }\end{array}$ & $\begin{array}{l}\text { Positive short- } \\
\text { term and long- } \\
\text { term relief }\end{array}$ \\
\hline
\end{tabular}

cluded in the evidence synthesis is illustrated in Table 2 for lumbar interlaminar epidural injections and Table 3 for cervical interlaminar epidural injections.

Two new interlaminar lumbar epidural steroid injections $(119,120)$ were included in lumbar interlaminar epidural evidence synthesis are described here.

Arden et al (120) evaluated 228 patients with "clinical" unilateral sciatica who were treated with either a lumbar epidural injection (80 $\mathrm{mg}$ triamcinolone in $10 \mathrm{~mL} 0.25 \%$ bupivacaine) or an interspinous ligament injection with $2 \mathrm{~mL}$ normal saline, performed blindly by "experienced anaesthetists." The patients underwent injections at 0,3 , and 6 weeks, although patients who noted at least $75 \%$ improvement in pain did not receive a second or third injection. The epidural injections produced a significant improvement in self-reported function at 3 weeks, but that benefit was lost by 6 weeks.

Wilson-MacDonald et al (119) compared lumbar epidural steroid injections to interspinous ligament steroid injections, to assess whether the epidural location of the steroid was responsible for the subsequent effects. Ninety-three patients with back and leg pain and MRI evidence of a prolapsed disc who had been offered surgery were randomized to receive either a blind lumbar epidural (44 patients) or an injection into the interspinous ligament (48 patients). Each patient was injected with 8
$\mathrm{mL} 0.5 \%$ bupivacaine and $80 \mathrm{mg}$ of methylprednisolone. There was no difference in the rate of subsequent surgery through the period of follow up.

Cost Effectiveness

In the evaluation of cost effectiveness, Manchikanti et al (85) and Price et al (160) concluded that lumbar interlaminar epidural steroid injections were not cost effective.

Level of Evidence

In managing lumbar radicular pain with interlaminar lumbar epidural steroid injections, the level of evidence is strong for short-term relief and limited for long-term relief. In managing cervical radiculopathy with cervical interlaminar epidural steroid injections, the evidence was moderate for short-term improvement and long-term improvement. The evidence is indeterminate in the management of axial neck pain, axial low back pain, and lumbar spinal stenosis.

\section{Transforaminal Epidural Injections}

Relevant reports evaluating the effectiveness of transforaminal epidural injections included 12 randomized trials, 20 prospective evaluations, and multiple retrospective reports $(121,122,130,161-212)$. Methodological Criteria

The evaluation for evidence synthesis led to identification of 12 randomized controlled trials $(116,162$ - 
172), and 20 prospective evaluations $(121,122,173$ 190), and multiple retrospective evaluations $(130,161,191-206)$. Of the 12 randomized controlled trials, 7 trials were included in evidence synthesis $(162-164,166,167,169,170)$, whereas of 20 prospective evaluations, 7 were included $(121,174,175,187-190)$. Karppinen et al (166) reported results of 1 study in 2 publications $(165,166)$. Thus, this was considered as one study. Multiple others were excluded for various reasons. A trial by Kolsi et al (168) was not included since the measurements were only of short-term duration. Kraemer et al (116) described lumbar epidural perineural injection, however, using an interlaminar approach, a non-validated technique. A summary of reported studies is listed in Table 4.

Among the 7 randomized trials included in the evidence synthesis meeting inclusion criteria, 6 of them evaluated effectiveness in lumbar disc herniation and radiculopathy $(162-164,166,169,170)$, showing mixed results in 4 of the 6 , both in short-term and long-term with 2 negative studies $(163,166)$. The 7th trial $(167)$ studied effectiveness in postsurgery syndrome with negative results.

Among the 7 prospective evaluations included for evaluation, 2 studies evaluated the effectiveness of cervical transforaminal epidurals $(121,189)$, showing positive results. The remaining 5 studies $(175,179,187,188,190)$ evaluated lumbar transforaminal epidural steroid injections. One study (188) compared effectiveness of transforaminal epidural steroid injections in lumbar spine with discectomy. One evaluation reported the effect on spinal stenosis (190). Multiple retrospective evaluations also showed positive results. Only one retrospective evaluation (130) was included in cervical transforaminal evidence synthesis. A summary of lumbar epidural transforaminal injections is described in Table 5, whereas, the summary of cervical transforaminal epidural injections is described in Table 6 .

Table 4. Details of randomized trials studying the effectiveness of lumbar transforaminal epidural steroid injections.

\begin{tabular}{|c|c|c|c|c|c|}
\hline Study/Methods & Participants & Intervention(s) & Outcome(s) & Result(s) & $\begin{array}{c}\text { Conclusion(s) } \\
\text { Short-term } \\
\text { relief }<6 \text { wks } \\
\text { Long-term } \\
\text { relief }>6 \text { wks }\end{array}$ \\
\hline $\begin{array}{l}\text { Riew et al }(162,164) \\
\text { Prospective, } \\
\text { randomized, } \\
\text { controlled, double- } \\
\text { blind study } \\
\text { AHRQ score: } 8 / 10 \\
\text { Cochrane score: } 7 / 10\end{array}$ & $\begin{array}{l}55 \text { pts with lumbar } \\
\text { disc herniations } \\
\text { or spinal stenosis } \\
\text { referred for surgical } \\
\text { evaluation. } \\
28 \text { pts in } \\
\text { experimental group } \\
\text { (bupivacaine and } \\
\text { betamethasone) } \\
\text { and } 27 \text { pts in } \\
\text { control group } \\
\text { (bupivacaine only). }\end{array}$ & $\begin{array}{l}\text { Experimental: } \\
\text { transforaminal nerve } \\
\text { root or epidural } \\
\text { steroid injection } \\
\text { with } 1 \mathrm{~mL} \text { of } 0.25 \% \\
\text { bupivacaine and } 6 \\
\text { mg of betamethasone } \\
\text { Control: } 1 \text { mL of } \\
0.25 \% \text { bupivacaine. As } \\
\text { many as } 4 \text { injections } \\
\text { were given during the } \\
\text { follow-up. }\end{array}$ & $\begin{array}{l}\text { Initial outcomes were } \\
\text { evaluated at } 1 \text { year. } \\
\text { Injection was considered } \\
\text { as a failure if the patient } \\
\text { opted for operative } \\
\text { treatment. North } \\
\text { American Spine Society } \\
\text { questionnaire also } \\
\text { used: } 20 \text { of } 28 \text { patients } \\
\text { in steroid group, } 9 \text { of } \\
27 \text { patients in control } \\
\text { group had no surgery at } \\
1 \text { year. After } 5 \text { yrs, with } \\
\text { no differences among } \\
\text { groups. }\end{array}$ & $\begin{array}{l}17 \text { of the } 21 \text { pts } \\
\text { still had successful } \\
\text { results with } \\
\text { no operative } \\
\text { intervention. }\end{array}$ & $\begin{array}{l}\text { Positive short- } \\
\text { term and long- } \\
\text { term relief }\end{array}$ \\
\hline $\begin{array}{l}\text { Ng et al (163) } \\
\text { Randomized, double- } \\
\text { blind, controlled trial } \\
\text { AHRQ score: } 8 / 10 \\
\text { Cochrane score: } 8 / 10\end{array}$ & $\begin{array}{l}43 \text { pts were } \\
\text { recruited in the } \\
\text { bupivacaine and } \\
\text { methylprednisolone } \\
\text { group and } 43 \text { pts } \\
\text { in the bupivacaine } \\
\text { only group with } \\
\text { radicular pain } \\
\text { who had unilateral } \\
\text { symptoms and also } \\
\text { failed conservative } \\
\text { management. }\end{array}$ & $\begin{array}{l}\text { One group received } \\
\text { bupivacaine and } \\
\text { methylprednisolone } \\
\text { and the second } \\
\text { group received only } \\
\text { bupivacaine with } \\
\text { a transforaminal } \\
\text { injection. }\end{array}$ & $\begin{array}{l}\text { Outcome measures: } \\
\text { the Oswestry Disability } \\
\text { Index, visual analogue } \\
\text { score for back pain and } \\
\text { leg pain, claudication in } \\
\text { walking distance, and } \\
\text { the patient's subjective } \\
\text { level of satisfaction of } \\
\text { the outcome. }\end{array}$ & $\begin{array}{l}47.5 \% \text { of pts in } \\
\text { the bupivacaine } \\
\text { only group had } \\
\text { at least } 20 \mathrm{~mm} \\
\text { reduction in leg } \\
\text { pain compared to } \\
41.5 \% \text { of pts in the } \\
\text { bupivacaine and } \\
\text { steroids group at } 3 \\
\text { months. }\end{array}$ & $\begin{array}{l}\text { Negative short- } \\
\text { term and long- } \\
\text { term relief }\end{array}$ \\
\hline
\end{tabular}


Table 4 Continued. Details of randomized trials studying the effectiveness of lumbar transforaminal epidural steroid injections.

\begin{tabular}{|c|c|c|c|c|c|}
\hline Study/Methods & Participants & Intervention(s) & Outcome(s) & Result(s) & $\begin{array}{c}\text { Conclusion(s) } \\
\text { Short-term } \\
\text { relief }<6 \mathrm{wks} \\
\text { Long-term } \\
\text { relief }>6 \mathrm{wks} \\
\end{array}$ \\
\hline $\begin{array}{l}\text { Karppinen et al (165, } \\
166) \\
\text { Randomized, double- } \\
\text { blind trial } \\
\text { AHRQ score: } 9 / 10 \\
\text { Cochrane score: } 8 / 10\end{array}$ & $\begin{array}{l}160 \text { consecutive, } \\
\text { eligible pts } \\
\text { with sciatica } \\
\text { with unilateral } \\
\text { symptoms of } 1 \text { to } \\
6 \text { mos duration. } \\
\text { None of the pts had } \\
\text { undergone surgery. }\end{array}$ & $\begin{array}{l}\text { Experimental: local } \\
\text { anesthetic and } \\
\text { methylprednisolone. } \\
\text { Control: normal } \\
\text { saline. }\end{array}$ & $\begin{array}{l}\text { Timing: } 2 \text { wks, } 3 \text { mos, } \\
\text { and } 6 \text { mos } \\
\text { Outcome measures: } \\
\text { Pain relief, sick } \\
\text { leave, medical costs, } \\
\text { and future surgery. } \\
\text { Nottingham Health } \\
\text { Profile. }\end{array}$ & $\begin{array}{l}\text { Steroid injection } \\
\text { produced } \\
\text { significant } \\
\text { treatment effects } \\
\text { and short-term in } \\
\text { leg pain, straight leg } \\
\text { raising, disability } \\
\text { and in Nottingham } \\
\text { Health Profile and } \\
\text { emotional reactions. }\end{array}$ & $\begin{array}{l}\text { Positive short- } \\
\text { term and long- } \\
\text { term relief }\end{array}$ \\
\hline $\begin{array}{l}\text { Vad et al (169) } \\
\text { Prospective, } \\
\text { randomized trials } \\
\text { AHRQ score: } 7 / 10 \\
\text { Cochrane score: } 7 / 10\end{array}$ & $\begin{array}{l}\text { Pts with leg pain, } \\
\text { with documented } \\
\text { herniated nucleus } \\
\text { pulposus or } \\
\text { manifested clinical } \\
\text { signs such as } \\
\text { radicular pain } \\
\text { with lumbar } \\
\text { radiculopathy. }\end{array}$ & $\begin{array}{l}\text { Experimental: } \\
\text { betamethasone } 9 \mathrm{mg} \text {, } \\
\text { and } 2 \% \text { preservative- } \\
\text { free Xylocaine }(1.5 \mathrm{~mL}) \\
\text { per level. } \\
\text { Control: trigger point } \\
\text { injections. }\end{array}$ & $\begin{array}{l}\text { Timing: } 3 \text { wks, } 6 \text { wks, } \\
3 \text { mos, } 6 \text { mos, and } 12 \\
\text { mos. } \\
\text { Outcome measures: } \\
\text { Roland-Morris score, } \\
\text { visual numeric score, } \\
\text { finger-to-floor distance, } \\
\text { patient satisfaction } \\
\text { score. }\end{array}$ & $\begin{array}{l}\text { Group receiving } \\
\text { transforaminal } \\
\text { epidural steroid } \\
\text { injections had } \\
84 \% \text { success rate } \\
\text { compared with } 48 \% \\
\text { for group receiving } \\
\text { trigger point } \\
\text { injections. }\end{array}$ & $\begin{array}{l}\text { Positive short- } \\
\text { term and long- } \\
\text { term relief }\end{array}$ \\
\hline $\begin{array}{l}\text { Devulder (167) } \\
\text { Open, non-blind, } \\
\text { randomized study } \\
\text { AHRQ Score: } 6 / 10 \\
\text { Cochrane Score: } \\
\text { 5/10. }\end{array}$ & $\begin{array}{l}60 \text { pts with } \\
\text { documented } \\
\text { epidural fibrosis in } \\
\text { fewer than three } \\
\text { nerve roots. }\end{array}$ & $\begin{array}{l}\text { Group A = } 1 \mathrm{~mL} \\
\text { bupivacaine } 0.5 \% \\
\text { with } 1500 \text { units } \\
\text { hyaluronidase and } 1 \mathrm{ml} \\
\text { saline per nerve root } \\
\text { sleeve. } \\
\text { Group B = } 1 \mathrm{~mL} \\
\text { bupivacaine } 0.5 \% \\
\text { with } 40 \mathrm{mg} \\
\text { methylprednisolone } \\
\text { solution per nerve root. } \\
\text { Group C = bupivacaine } \\
0.5 \% \text { combined } \\
\text { with } 1500 \text { units } \\
\text { hyaluronidase and } 40 \\
\text { mg methylprednisolone } \\
\text { solution. The volume } \\
\text { of each injection was } 2 \\
\text { ml and each was given } \\
\text { twice at an interval of } \\
1 \text { wk. }\end{array}$ & $\begin{array}{l}\text { The pts were evaluated } \\
\text { on a verbal pain } \\
\text { rating scale } 1,3 \text {, and } 6 \\
\text { mos after the second } \\
\text { injection. The Kruskal- } \\
\text { Wallis test was used } \\
\text { to detect statistically } \\
\text { significant differences } \\
\text { among the three } \\
\text { groups, and the analysis } \\
\text { was refined with the } \\
\text { Friedman test. }\end{array}$ & $\begin{array}{l}\text { Overall, although } \\
\text { injections induced } \\
\text { analgesia at } 1 \\
\text { month, these effects } \\
\text { were reduced at 3- } \\
\text { and 6-month follow- } \\
\text { ups. No statistical } \\
\text { differences were } \\
\text { found between the } \\
3 \text { treatment groups } \\
\text { after } 1 \text { month. }\end{array}$ & $\begin{array}{l}\text { Negative short- } \\
\text { term and long- } \\
\text { term relief }\end{array}$ \\
\hline $\begin{array}{l}\text { Thomas (170) } \\
\text { Randomized, } \\
\text { controlled trials } \\
\text { AHRQ Score: } 6 / 10 \\
\text { Cochrane Score: } 5 / 10\end{array}$ & $\begin{array}{l}\text { Thirty-one pts } \\
\text { (18 females, } 13 \\
\text { males) with discal } \\
\text { radicular pain of } \\
\text { less than } 3 \text { mos } \\
\text { duration. }\end{array}$ & $\begin{array}{l}\text { Pts were consecutively } \\
\text { randomized to receive } \\
\text { either radio-guided } \\
\text { transforaminal or } \\
\text { blindly performed } \\
\text { interspinous epidural } \\
\text { corticosteroid } \\
\text { injections. }\end{array}$ & $\begin{array}{l}\text { Post-treatment outcome } \\
\text { was evaluated clinically } \\
\text { at } 6 \text { and } 30 \text { days, and } \\
6 \text { mos. } \\
\text { Outcome measures: } \\
\text { pain, functional status. }\end{array}$ & $\begin{array}{l}\text { At day } 30 \text { and } 6 \\
\text { mos, pain relief, } \\
\text { daily activities, } \\
\text { work, leisure } \\
\text { activities, anxiety, } \\
\text { and depression, } \\
\text { were better in } \\
\text { transforaminal } \\
\text { group. }\end{array}$ & $\begin{array}{l}\text { Positive short- } \\
\text { term and long- } \\
\text { term relief }\end{array}$ \\
\hline
\end{tabular}


Pain Physician: January 2007 10:185-212

Table 5. Details and results of nonrandomized trials of lumbar transforaminal epidural injections.

\begin{tabular}{|c|c|c|c|c|c|}
\hline Study/Methods & Participants & Intervention(s) & Outcome(s) & Result(s) & $\begin{array}{l}\text { Conclusion(s) } \\
\text { Short-term } \\
\text { relief }<6 \mathrm{wks} \\
\text { Long-term } \\
\text { relief }>6 \mathrm{wks} \\
\end{array}$ \\
\hline $\begin{array}{l}\text { Lutz et al (179) } \\
\text { A prospective } \\
\text { case series } \\
\text { AHRQ score: } 4 / 8\end{array}$ & $\begin{array}{l}69 \text { pts with lumbar } \\
\text { herniated nucleus } \\
\text { pulposus and } \\
\text { radiculopathy were } \\
\text { recruited. }\end{array}$ & $\begin{array}{l}\text { Transforaminal } \\
\text { epidural steroid } \\
\text { injections with } 1.5 \\
\text { cc of } 2 \% \text { Xylocaine } \\
\text { and } 9 \mathrm{mg} \text { of } \\
\text { betamethasone } \\
\text { acetate. }\end{array}$ & $\begin{array}{l}\text { Timing: } 28 \text { to } 144 \text { wks. } \\
\text { Outcome measures: At } \\
\text { least } \pm 50 \% \text { reduction } \\
\text { in preinjection and } \\
\text { postinjection visual } \\
\text { numerical pain scores. }\end{array}$ & $\begin{array}{l}\text { A successful outcome } \\
\text { was reported by } 52 \text { of } \\
\text { the } 69 \text { pts (75.4\%) at an } \\
\text { average follow-up of } 80 \\
\text { wks (range } 28-144 \text { wks). }\end{array}$ & $\begin{array}{l}\text { Positive short-term } \\
\text { and long-term } \\
\text { relief }\end{array}$ \\
\hline $\begin{array}{l}\text { Butterman (187) } \\
\text { A prospective } \\
\text { evaluation } \\
\text { AHRQ score: } 4 / 8\end{array}$ & $\begin{array}{l}232 \text { pts who } \\
\text { were referred } \\
\text { for treatment of } \\
\text { DDD, } 171 \text { pts } \\
\text { who were possible } \\
\text { spinal arthrodesis } \\
\text { candidates. }\end{array}$ & $\begin{array}{l}\text { Transforaminal } \\
\text { epidural steroid } \\
\text { injections or } \\
\text { intradiscal steroid } \\
\text { injections (ISIs). }\end{array}$ & $\begin{array}{l}\text { Visual analog pain } \\
\text { scale, pain drawing, } \\
\text { Oswestry Disability. } \\
\text { Index, use of pain } \\
\text { medication, and } \\
\text { opinion of treatment } \\
\text { success. }\end{array}$ & $\begin{array}{l}\text { ESI was effective in } \\
\text { improving pain and } \\
\text { function at short-term } \\
\text { follow-up. At } 2 \text { years, } \\
\text { less than one-third } \\
\text { had not had additional } \\
\text { invasive treatment. }\end{array}$ & $\begin{array}{l}\text { Positive short-term } \\
\text { and negative long- } \\
\text { term relief }\end{array}$ \\
\hline $\begin{array}{l}\text { Butterman (188) } \\
\text { A prospective } \\
\text { evaluation } \\
\text { AHRQ score: } 4 / 8\end{array}$ & $\begin{array}{l}169 \text { pts with a large } \\
\text { herniation of the } \\
\text { lumbar nucleus } \\
\text { pulposus. }\end{array}$ & $\begin{array}{l}\text { Transforaminal } \\
\text { epidural steroid } \\
\text { injection or } \\
\text { discectomy. }\end{array}$ & $\begin{array}{l}\text { Evaluation was } \\
\text { performed with the } \\
\text { use of outcomes scales } \\
\text { and neurological } \\
\text { examination. }\end{array}$ & $\begin{array}{l}42 \% \text { to } 56 \% \text { of the } 50 \text { pts } \\
\text { who had epidural steroid } \\
\text { injection reported that } \\
\text { the treatment had been } \\
\text { effective. }\end{array}$ & $\begin{array}{l}\text { Positive short-term } \\
\text { and long-term } \\
\text { relief }\end{array}$ \\
\hline $\begin{array}{l}\text { Botwin et al (190) } \\
\text { A prospective } \\
\text { evaluation } \\
\text { AHRQ score: } 4 / 8\end{array}$ & $\begin{array}{l}34 \text { pts who met our } \\
\text { inclusion criteria } \\
\text { for the treatment } \\
\text { of unilateral } \\
\text { radicular pain from } \\
\text { degenerative lumbar } \\
\text { spinal stenosis. }\end{array}$ & $\begin{array}{l}\text { Injectant: } 12 \mathrm{mg} \\
\text { of betamethasone } \\
\text { acetate and } \\
2 \mathrm{~mL} \text { of } 1 \% \\
\text { preservative-free } \\
\text { lidocaine HCL. }\end{array}$ & $\begin{array}{l}\text { Pts were evaluated } \\
\text { by an independent } \\
\text { observer at } 2 \text { mos, } \\
\text { and at } 12 \text { mos after } \\
\text { the injections. } \\
\text { Questionnaires: visual } \\
\text { analog scale, Roland } \\
\text { 5-point pain scale, } \\
\text { standing/walking } \\
\text { tolerance, and patient } \\
\text { satisfaction scale. }\end{array}$ & $\begin{array}{l}75 \% \text { of pts had } \\
\text { successful long-term } \\
\text { outcome, reporting at } \\
\text { least a }>50 \% \text { reduction } \\
\text { between preinjection } \\
\text { and postinjection pain } \\
\text { scores, with an average } \\
\text { of } 1.9 \text { injections per } \\
\text { patient. } 64 \% \text { of pts } \\
\text { had improved walking } \\
\text { tolerance, and } 57 \% \\
\text { had improved standing } \\
\text { tolerance at } 12 \text { mos. }\end{array}$ & $\begin{array}{l}\text { Positive short-term } \\
\text { and long-term } \\
\text { relief }\end{array}$ \\
\hline $\begin{array}{l}\text { Yang et al (175) } \\
\text { A prospective } \\
\text { evaluation } \\
\text { AHRQ score: } 4 / 8\end{array}$ & $\begin{array}{l}21 \text { patients } \\
\text { with lumbar } \\
\text { radiculopathy were } \\
\text { evaluated. All of } \\
\text { them had a CT or } \\
\text { MRI visualized disc } \\
\text { herniations and were } \\
\text { felt to be candidates } \\
\text { for discectomy. }\end{array}$ & $\begin{array}{l}\text { Transforaminal } \\
\text { epidural steroid } \\
\text { injection. }\end{array}$ & $\begin{array}{l}\text { Pain relief and } \\
\text { avoidance of surgery. }\end{array}$ & $\begin{array}{l}63 \% \text { of patients had } \\
\text { significant pain relief } \\
\text { lasting through the } \\
\text { 23-month follow-up, } \\
\text { avoiding surgery. }\end{array}$ & $\begin{array}{l}\text { Positive short-term } \\
\text { and long-term } \\
\text { relief }\end{array}$ \\
\hline
\end{tabular}

\section{Description of Study Characteristics}

Riew et al (162) performed an evaluation of minimum 5-year follow-up to evaluate nerve root blocks in the treatment of lumbar radicular pain. This was a continuation of a previous randomized, double-blind, controlled study on the effect of nerve root blocks on the need for operative treatment of lumbar radicular pain (164). All of the patients in both studies $(162,164)$ were considered to be operative candidates by the treating surgeon and all had initially requested operative intervention. They had then been randomized to be treated with a selective nerve root block with either bupivacaine or bupivacaine and betamethasone. Both the treating physician and the patient were 
Epidural Steroids in the Management of Chronic Spinal Pain

Table 6. Details and results of non-randomized trials of cervical transforaminal epidural injections.

\begin{tabular}{|c|c|c|c|c|c|}
\hline Study/Methods & Participants & Intervention(s) & Outcome(s) & Result(s) & $\begin{array}{c}\text { Conclusion(s) } \\
\text { Short-term } \\
\text { relief }<6 \mathrm{wks} \\
\text { Long-term } \\
\text { relief }>6 \mathrm{wks}\end{array}$ \\
\hline $\begin{array}{l}\text { Bush and Hillier (121) } \\
\text { A prospective } \\
\text { evaluation } \\
\text { AHRQ score: } 4 / 8\end{array}$ & $\begin{array}{l}68 \text { pts with neck } \\
\text { pain and cervical } \\
\text { radiculopathy. }\end{array}$ & $\begin{array}{l}\text { Transforaminal } \\
\text { cervical epidural } \\
\text { steroid injections. }\end{array}$ & $\begin{array}{l}\text { Timing: } 1 \text { month to } 1 \\
\text { year. } \\
\text { Outcome measures: } \\
\text { Pain relief. }\end{array}$ & $\begin{array}{l}93 \% \text { of the pts were } \\
\text { reported to have } \\
\text { good pain relief } \\
\text { lasting for } 7 \text { mos. }\end{array}$ & $\begin{array}{l}\text { Positive short- } \\
\text { term and long- } \\
\text { term relief. }\end{array}$ \\
\hline $\begin{array}{l}\text { Cyteval et al (189) } \\
\text { AHRQ score: } 4 / 8\end{array}$ & $\begin{array}{l}30 \text { pts with cervical } \\
\text { radiculopathy, } 16 \\
\text { pts with foraminal } \\
\text { degenerative } \\
\text { stenosis, } 14 \text { pts with } \\
\text { disk herniation. }\end{array}$ & $\begin{array}{l}\text { Periradicular } \\
\text { foraminal steroid } \\
\text { infiltration under } \\
\text { CT control. }\end{array}$ & $\begin{array}{l}\text { Timing: } 2 \text { wks, } 6 \text { mos. } \\
\text { Outcome measures: } \\
\text { visual analog pain scale } \\
\text { (VAS). }\end{array}$ & $\begin{array}{l}\text { Good pain relief was } \\
\text { reported in } 60 \% \text { of } \\
\text { pts. There was no } \\
\text { rebound of pain at } \\
\text { the } 6 \text {-month follow- } \\
\text { up. }\end{array}$ & $\begin{array}{l}\text { Positive short- } \\
\text { term and long- } \\
\text { term relief }\end{array}$ \\
\hline $\begin{array}{l}\text { Kolstad et al (174) } \\
\text { A prospective } \\
\text { evaluation } \\
\text { AHRQ score: } 4 / 8\end{array}$ & $\begin{array}{l}21 \text { patients } \\
\text { awaiting cervical } \\
\text { disc surgery. }\end{array}$ & $\begin{array}{l}\text { Patients were } \\
\text { given } 2 \text { epidural } \\
\text { injections } 2 \text { weeks } \\
\text { apart. }\end{array}$ & $\begin{array}{l}\text { Outcome assessments: } 6 \\
\text { weeks and } 4 \text { mos . } \\
\text { Outcome measures: } \\
\text { VAS, Odom's criterion, } \\
\text { and treatment } \\
\text { satisfaction. }\end{array}$ & $\begin{array}{l}5 \text { of the } 21 \text { patients } \\
\text { canceled their } \\
\text { surgery due to } \\
\text { improvement in pain, } \\
\text { and overall, there was } \\
\text { a significant decrease } \\
\text { in radicular pain at } 6 \\
\text { weeks and } 4 \text { months. }\end{array}$ & $\begin{array}{l}\text { Positive short- } \\
\text { term and long- } \\
\text { term relief }\end{array}$ \\
\hline $\begin{array}{l}\text { Lin et al (130) } \\
\text { A retrospective study } \\
\text { AHRQ score: } 4 / 8\end{array}$ & $\begin{array}{l}\text { Patients with } \\
\text { herniated cervical } \\
\text { discs, otherwise } \\
\text { surgical candidates } \\
\text { were offered a trial } \\
\text { of cervical epidural } \\
\text { injections. }\end{array}$ & $\begin{array}{l}\text { Cervical } \\
\text { transforaminal } \\
\text { with local } \\
\text { anesthetic and } \\
\text { steroids. }\end{array}$ & $\begin{array}{l}\text { Pain relief and } \\
\text { avoidance of surgery. }\end{array}$ & $\begin{array}{l}\text { Of the } 70 \text { treated } \\
\text { patients, } 44(63 \%) \\
\text { had significant relief } \\
\text { of their symptoms } \\
\text { and did not wish to } \\
\text { proceed with surgical } \\
\text { treatment. }\end{array}$ & $\begin{array}{l}\text { Positive short- } \\
\text { term and long- } \\
\text { term relief }\end{array}$ \\
\hline
\end{tabular}

blinded to the type of medication. Of the 55 randomized patients, 29 avoided an operation in the original study. Twenty-one of those 29 patients were reevaluated with a follow-up questionnaire at a minimum of 5 years after the initial block; 17 of 21 patients still had not had operative intervention. There was no difference between the group treated with bupivacaine alone and the group treated with bupivacaine and betamethasone with regard to the avoidance of surgery for 5 years. At the 5-year follow-up evaluation, all of the patients who had avoided operative treatment had significant decreases in neurological symptoms and back pain compared with baseline values. Authors concluded that the majority of patients with lumbar radicular pain who avoid an operation for at least 1 year after receiving a nerve root injection with bupivacaine along or in combination with betamethasone will continue to avoid operative intervention for a minimum of 5 years.
$\mathrm{Ng}$ et al (163) studied periradicular infiltration of nerve roots with local anesthetic and steroid versus local anesthetic alone. They evaluated 86 patients with unilateral leg pain and an MRI showing a lumbar herniated disc or foraminal stenosis at a level compatible with the symptoms. All the patients received a single level injection under fluoroscopy with $2 \mathrm{~mL}$ of $0.25 \%$ bupivacaine with $40 \mathrm{mg}$ of methylprednisolone in 1 group and the second group receiving only bupivacaine alone. The results showed no significant difference between the groups. In both groups, there was only a modest decrease in VAS at 3 months. Criticism of this study is that only 1 injection was offered.

Karppinen et al $(165,166)$ evaluated transforaminal epidural steroid injections in patients with MRIconfirmed herniated nucleus pulposus. The outcome measures were $50 \%$ relief of leg pain and cost effectiveness. Vad et al (169) evaluated transforaminal epidural steroid injections and compared them to 
patients undergoing lumbar paraspinal trigger point injections with sodium chloride solution. The outcome measures included improvement in leg pain, RolandMorris score, and patient satisfaction score.

Thomas et al (170) evaluated the effectiveness of transforaminal epidural and compared it with interspinous corticosteroid injection. Devulder et al (167) used a combination of methylprednisolone, bupivacaine, and hyaluronidase and compared this to a combination of sodium chloride solution, bupivacaine, and hyaluronidase. The outcome measures were reduction in leg pain of at least $50 \%$.

Kolstad et al (174) studied cervical transforaminal epidural steroids on 21 patients awaiting cervical disc surgery. Patients were given 2 epidural injections 2 weeks apart, and followed for 4 months. Three outcome assessments were performed at baseline, 6 weeks, and 4 months. Outcome measures included visual analogue scale pain intensity $(0-100 \mathrm{~mm})$ for neck pain, visual analogue scale pain intensity $(0-100 \mathrm{~mm})$ for radicular pain, and Odom's Criteria-a grading system to evaluate relief of symptoms and treatment satisfaction (1: Excellent, 2: Good, 3: Fair, 4: Poor). Five of the 21 patients canceled their surgery due to improvement in pain, and overall there was a significant decrease in radicular pain at 6 weeks and 4 months. Neck pain also improved, and patients with spondylosis responded as well as patients with disc herniations.

Among the prospective evaluations, the effect of transforaminal epidural steroids on candidates for discectomy was studied by Yang et al (175). They evaluated 21 lumbar radiculopathy patients, all of whom had CT or MRI visualized disc herniations, all of whom were felt to be candidates for discectomy. Sixty-three percent of the patients had significant pain relief lasting through the 24-month follow-up, avoiding surgery; the transforaminal epidural resulted in significant relief of leg pain and improvement in activities of daily living, but did not improve low back pain.

A retrospective review of cervical transforaminal steroid injections was published by Lin et al (130). They evaluated 70 patients in a retrospective evaluation with cervical disc herniation without myelopathy. The average follow-up was 13 months ( 6 months to 4 years), and the number of injections ranged from 1 to 4 (mean 1.46). At 1-year follow-up $63 \%$ of the patients had improved and avoided surgery.

\section{Cost Effectiveness}

Cost effectiveness of transforaminal epidural steroid injections in the management of chronic low back pain showed that cost per 1-year improvement of quality of life was $\$ 2,927$ per year (85). Further, in patients treated with transforaminal steroids, operations were avoided for contained herniations, costing $\$ 12,666$ less per responder in the steroid group (166). Cost effectiveness was also demonstrated by avoiding surgical intervention $(130,162,164,174)$.

Level of Evidence

The evidence for lumbar transforaminal epidural steroid injections in managing lumbar nerve root pain is strong for short-term and moderate for long-term improvement. The evidence for cervical transforaminal epidural steroid injections in managing cervical nerve root pain is moderate for short-term and longterm improvement. The evidence is limited in managing lumbar radicular pain in postlumbar laminectomy syndrome. The evidence is indeterminate in managing axial low back pain, axial neck pain, and lumbar disc extrusions.

\section{Caudal Epidural Injections}

Relevant reports studying caudal epidural injections included 11 randomized $(99,207-216), 5$ prospective evaluations (217-221), and multiple retrospective evaluations $(3,16-19,84,85,222-224)$. The results of published reports of the randomized trials are described in Table 7, while Table 8 shows descriptions of prospective evaluations.

Of the 11 randomized trials, 3 trials were excluded $(208,212,213)$. One study $(213)$ was excluded due to non-availability of analyzable information, whereas a second trial (212) was excluded due to lack of longterm data. A recent study (208) was excluded due to poor protocol design and short-term relief and lack of fluoroscopy in the modern era.

Of the 8 randomized trials, 6 trials predominantly evaluated patients with disc herniation or radiculitis $(99,207,209-211,214), 2$ trials evaluated patients suffering with pain following failed back surgery syndrome $(215,216)$, and one study (214) evaluated a mixed population with $50 \%$ postlumbar laminectomy syndrome patients. One study (99) compared blind interlaminar epidurals with caudal epidural steroid injections. One study (208) evaluated the effectiveness of triamcinolone acetonide and methylprednisolone acetate.

Among the 5 nonrandomized evaluations (217221), disc herniation or radiculitis patients were studied in 2 evaluations $(219,220)$, the role of caudal epidural in chronic low back pain was studied in an additional 
2 studies $(217,218)$, and the role of caudal epidural steroids was studied in spinal stenosis in one study (221).

\section{Description of Study Characteristics}

Descriptive characteristics of the included randomized trials are shown in Table 7 and non-randomized trials in Table 8.

Dashfield et al (207) compared the effectiveness of caudal steroid epidural with targeted steroid placement during spinal endoscopy for chronic sciatica in a prospective, randomized, double-blind trial. They studied 60 patients referred to their clinic for management of sciatica of greater than 6 months but less than 18 months' duration. The sciatica was defined as pain in the distribution of a lumbar nerve root, accompanied by neurosensory and motor deficits, with or without low back pain. Patients were 18 years of age or older. Patients who had previous spinal surgery, coagulopathy, progressive motor neuron disorders, or peripheral vascular disease were excluded, as were patients who had received an epidural corticosteroid injection within 3 months of being randomized. Patients were allocated randomly into 2 groups. Patients in the caudal group underwent caudal epidural corticosteroid injection with a total of $10 \mathrm{~mL}$ of lidocaine $1 \%$ with $40 \mathrm{mg}$ of triamcinolone being injected into the epidural space. Patients in the epiduroscopy group underwent epiduroscopy performed by an experienced epiduroscopist with placement of steroid over the nerve root, which included $10 \mathrm{~mL}$ of lidocaine $1 \%$ with triamcinolone 40 $\mathrm{mg}$. The epiduroscopy group also received infusion of 50 to $150 \mathrm{mg} \mathrm{mL}$ of sodium chloride solution. If adhesions were encountered around the painful nerve root, an attempt was made to break adhesions down using saline boluses or by manipulating the endoscope. However, very little scar tissue was encountered in their patient population, as they never had previous surgery.

Table 7. Characteristics of published randomized trials of caudal epidural injections.

\begin{tabular}{|c|c|c|c|c|c|}
\hline Study/Methods & Participants & Intervention(s) & Outcome(s) & Result(s) & $\begin{array}{c}\text { Conclusion(s) } \\
\text { Short-term } \\
\text { relief }<6 \mathrm{wks} \\
\text { Long-term } \\
\text { relief }>6 \mathrm{wks}\end{array}$ \\
\hline $\begin{array}{l}\text { Dashfield (207) } \\
\text { Prospective, } \\
\text { randomized, double- } \\
\text { blind trial } \\
\text { AHRQ score: } 9 / 10 \\
\text { Cochrane score: } 8 / 10\end{array}$ & $\begin{array}{l}60 \text { pts presenting } \\
\text { to the pain } \\
\text { management } \\
\text { center. }\end{array}$ & $\begin{array}{l}\text { Corticosteroid injection } \\
\text { with a total of } 10 \mathrm{~mL} \text { of } \\
\text { lidocaine } 1 \% \text { with } 40 \mathrm{mg} \\
\text { of triamcinolone } \\
\text { Epiduroscopy group: } \\
\text { delivery of the medication } \\
\text { over the painful nerve } \\
\text { root with } 10 \mathrm{~mL} \text { of } \\
\text { lidocaine } 1 \% \text { with } 40 \mathrm{mg} \\
\text { of triamcinolone. }\end{array}$ & $\begin{array}{l}\text { Assessments: } 6 \text { wks, } 3 \\
\text { mos, and } 6 \text { mos. } \\
\text { Outcome instruments: } \\
\text { SF-MPQ and HAD. }\end{array}$ & $\begin{array}{l}\text { Caudal group: } \\
\text { significant } \\
\text { improvements were } \\
\text { found for descriptive } \\
\text { pain at } 6 \text { mos; VAS at } \\
6 \text { wks, } 3 \text { mos, and } 6 \\
\text { months; present pain } \\
\text { intensity at } 3 \text { mos } \\
\text { and } 6 \text { mos; anxiety at } \\
6 \text { wks, } 3 \text { mos, and } 6 \\
\text { mos; and depression at } \\
6 \text { mos only. }\end{array}$ & $\begin{array}{l}\text { Positive short- } \\
\text { term and long- } \\
\text { term relief }\end{array}$ \\
\hline $\begin{array}{l}\text { McGregor et al (99) } \\
\text { Prospective } \\
\text { AHRQ score: } 6 / 10 \\
\text { Cochrane score: } 5 / 10\end{array}$ & $\begin{array}{l}44 \text { pts with low } \\
\text { back and leg pain. }\end{array}$ & $\begin{array}{l}\text { Caudal epidural vs } \\
\text { lumbar epidural. }\end{array}$ & Visual Analog Scale. & $\begin{array}{l}\text { No significant } \\
\text { improvement. }\end{array}$ & $\begin{array}{l}\text { Negative short- } \\
\text { term and long- } \\
\text { term relief }\end{array}$ \\
\hline $\begin{array}{l}\text { Breivik et al (209) } \\
\text { Randomized, double- } \\
\text { blind trial } \\
\text { AHRQ score: } 8 / 10 \\
\text { Cochrane score: } 7 / 10\end{array}$ & $\begin{array}{l}35 \text { pts with } \\
\text { incapacitating } \\
\text { chronic low back } \\
\text { pain and sciatica. } \\
\text { Diagnosis based } \\
\text { on radiculopathy: } \\
\text { arachnoiditis }(n=8) \text {, } \\
\text { no abnormality } \\
\text { ( } \mathrm{n}=11) \text {, inconclusive } \\
\text { findings ( } \mathrm{n}=5) \text {. } \\
\text { Duration: several } \\
\text { mos to several yrs. }\end{array}$ & $\begin{array}{l}\text { Caudal epidural } \\
\text { injection: Experimental: } \\
20 \mathrm{~mL} \text { bupivacaine } \\
0.25 \% \text { with } 80 \mathrm{mg} \\
\text { depomethylprednisone } \\
\text { ( } \mathrm{n}=16 \text { ) Placebo: } 20 \\
\mathrm{~mL} \text { bupivacaine } 0.25 \% \\
\text { followed by } 100 \mathrm{~mL} \text { saline } \\
(\mathrm{n}=19) \text {. Frequency: up to } \\
\text { three injections at weekly } \\
\text { intervals. }\end{array}$ & $\begin{array}{l}\text { Timing: not mentioned. } \\
\text { Outcome measures: } \\
\text { 1. Pain relief: } \\
\text { significant diminution } \\
\text { of pain and/or paresis } \\
\text { to a degree that } \\
\text { enabled return to work. } \\
\text { 2. Objective } \\
\text { improvement: } \\
\text { sensation, Lasègue's test, } \\
\text { paresis, spinal reflexes, } \\
\text { and sphincter disorders. }\end{array}$ & $\begin{array}{l}56 \% \text { of the pts } \\
\text { reported considerable } \\
\text { pain relief in } \\
\text { experimental group } \\
\text { compared to } 26 \% \text { of } \\
\text { the pts in the placebo } \\
\text { group. }\end{array}$ & $\begin{array}{l}\text { Positive short- } \\
\text { term and long- } \\
\text { term relief }\end{array}$ \\
\hline
\end{tabular}


Table 7 Continued. Characteristics of published randomized trials of caudal epidural injections.

\begin{tabular}{|c|c|c|c|c|c|}
\hline Study/Methods & Participants & Intervention(s) & Outcome(s) & Result(s) & $\begin{array}{c}\text { Conclusion(s) } \\
\text { Short-term } \\
\text { relief }<6 \mathrm{wks} \\
\text { Long-term } \\
\text { relief }>6 \mathrm{wks}\end{array}$ \\
\hline $\begin{array}{l}\text { Bush and Hillier (210) } \\
\text { Randomized, double- } \\
\text { blind trial } \\
\text { AHRQ score: } 8 / 10 \\
\text { Cochrane score: } 8 / 10\end{array}$ & $\begin{array}{l}23 \text { pts with } \\
\text { lumbar nerve } \\
\text { root compromise } \\
\text { randomized into } 2 \\
\text { groups. }\end{array}$ & $\begin{array}{l}\text { Experimental: } 25 \mathrm{~mL} \text { : } \\
80 \mathrm{mg} \text { triamcinolone } \\
\text { acetonide }+0.5 \% \\
\text { procaine hydrochloride } \\
(\mathrm{n}=12) \text {; Control: } 25 \mathrm{~mL} \\
\text { normal saline }(\mathrm{n}=11) \text {. } \\
\text { Frequency: two caudal } \\
\text { injections, the first after } \\
\text { admission to the trial and } \\
\text { a second after } 2 \text { wks. }\end{array}$ & $\begin{array}{l}\text { Timing: } 4 \text { wks and at } \\
1 \text { year. } \\
\text { Outcome measures: } \\
\text { 1. Effect on lifestyle; } \\
\text { 2. Back and leg pain; } \\
\text { 3. Angle of positive } \\
\text { SLR. }\end{array}$ & $\begin{array}{l}\text { Significantly better } \\
\text { results with pain and } \\
\text { straight leg raising in } \\
\text { experimental group in } \\
\text { short-term. Pain not } \\
\text { significantly different } \\
\text { but straight leg raise } \\
\text { significantly better for } \\
\text { long-term relief. }\end{array}$ & $\begin{array}{l}\text { Positive } \\
\text { short-term and } \\
\text { negative long- } \\
\text { term relief }\end{array}$ \\
\hline $\begin{array}{l}\text { Matthews et al (211) } \\
\text { Randomized, double- } \\
\text { blind trial } \\
\text { AHRQ score: } 8 / 10 \\
\text { Cochrane score: } 7 / 10\end{array}$ & $\begin{array}{l}57 \text { pts with sciatica } \\
\text { with a single root } \\
\text { compression } \\
\text { Experimental group: } \\
\text { male/female: } 19 / 4 \text {, } \\
\text { median duration of } \\
\text { pain: } 4 \text { wks. Control } \\
\text { group: male/female: } \\
\text { 24/10, median } \\
\text { duration of pain: } 4 \\
\text { wks. }\end{array}$ & $\begin{array}{l}\text { Experimental: } 20 \mathrm{~mL} \\
\text { bupivacaine } 0.125 \% \\
+2 \mathrm{~mL}(80 \mathrm{mg}) \\
\text { methylprednisolone } \\
\text { acetate }(\mathrm{n}=23) \text {. } \\
\text { Control: } 2 \mathrm{~mL} \text { lignocaine } \\
\text { (over the sacral hiatus or } \\
\text { into a tender spot) }(\mathrm{n}=34) \\
\text { Frequency: fortnightly } \\
\text { intervals, up to } 3 \text { times as } \\
\text { needed. }\end{array}$ & $\begin{array}{l}\text { Timing: } 2 \text { wks, } 1 \text {, } \\
3,6 \text {, and } 12 \text { mos. } \\
\text { Outcome measures: } \\
\text { pain (recovered vs not } \\
\text { recovered), range of } \\
\text { movement, straight } \\
\text { leg raising, neurologic } \\
\text { examination. }\end{array}$ & $\begin{array}{l}\text { There was no } \\
\text { significant difference } \\
\text { between experimental } \\
\text { and control group } \\
\text { with short-term } \\
\text { relief ( } 67 \% \text { vs } 56 \%) \text {. } \\
\text { After } 3 \text { mos, pts in } \\
\text { experimental group } \\
\text { reported significantly } \\
\text { more pain-free than in } \\
\text { control group. }\end{array}$ & $\begin{array}{l}\text { Negative } \\
\text { short-term and } \\
\text { positive long- } \\
\text { term relief }\end{array}$ \\
\hline $\begin{array}{l}\text { Helsa and Breivik } \\
(214) \\
\text { Randomized, } \\
\text { double-blind trial } \\
\text { with crossover design } \\
\text { AHRQ score: } 7 / 10 \\
\text { Cochrane score: } 7 / 10\end{array}$ & $\begin{array}{l}69 \text { pts with } \\
\text { incapacitating } \\
\text { chronic low back } \\
\text { pain and sciatica. } \\
36 \text { of } 69 \text { previously } \\
\text { been operated on } \\
\text { for herniated disc. }\end{array}$ & $\begin{array}{l}\text { Three caudal epidural } \\
\text { injections of either } \\
\text { bupivacaine with } \\
\text { depomethylprednisolone } \\
80 \mathrm{mg} \text { or with } \\
\text { bupivacaine followed by } \\
\text { normal saline. }\end{array}$ & $\begin{array}{l}\text { Timing: not } \\
\text { mentioned. Outcome } \\
\text { measures: significant } \\
\text { improvement to } \\
\text { return to work or to be } \\
\text { retrained for another } \\
\text { occupation. }\end{array}$ & $\begin{array}{l}34 \text { of the } 58 \text { pts }(59 \%) \\
\text { receiving caudal } \\
\text { epidural injections of } \\
\text { bupivacaine and } \\
\text { depomethylprednisol- } \\
\text { one showed significant } \\
\text { improvement. } \\
12 \text { of } 49 \text { pts ( } 25 \%) \text { who } \\
\text { received bupivacaine } \\
\text { followed by saline } \\
\text { were improved. }\end{array}$ & $\begin{array}{l}\text { Positive short- } \\
\text { term and long- } \\
\text { term relief. }\end{array}$ \\
\hline $\begin{array}{l}\text { Revel et al (215) } \\
\text { Randomized trial } \\
\text { AHRQ score: } 7 / 10 \\
\text { Cochrane score: } 6 / 10\end{array}$ & $\begin{array}{l}60 \text { postlumbar } \\
\text { laminectomy pts } \\
\text { with chronic low } \\
\text { back pain. }\end{array}$ & $\begin{array}{l}\text { Forceful caudal injection: } \\
\text { Experimental: } 125 \mathrm{mg} \text { of } \\
\text { prednisolone acetate with } \\
40 \mathrm{~mL} \text { of normal saline in } \\
\text { the treatment group. } \\
\text { Control: } 125 \mathrm{mg} \text { of } \\
\text { prednisolone in the } \\
\text { control group. }\end{array}$ & $\begin{array}{l}\text { Timing: } 6 \text { mos. } \\
\text { Outcome measures: } \\
\text { pain relief. }\end{array}$ & $\begin{array}{l}\text { The proportion of pts } \\
\text { relieved of sciatica was } \\
49 \% \text { in the forceful } \\
\text { injection group } \\
\text { compared to } 19 \% \text { in } \\
\text { the control group with } \\
\text { significant difference. }\end{array}$ & $\begin{array}{l}\text { Positive } \\
\text { short-term and } \\
\text { negative long- } \\
\text { term relief }\end{array}$ \\
\hline $\begin{array}{l}\text { Meadeb et al (216) } \\
\text { Randomized trial } \\
\text { Parallel-group study } \\
\text { AHRQ score: } 6 / 10 \\
\text { Cochrane score: } 6 / 10\end{array}$ & $\begin{array}{l}47 \text { postlumbar } \\
\text { laminectomy } \\
\text { syndrome pts in a } \\
\text { multicenter study. }\end{array}$ & $\begin{array}{l}\text { Experimental: forceful } \\
\text { injection of } 20 \mathrm{~mL} \text { of } \\
\text { normal saline with/with- } \\
\text { out } 125 \mathrm{mg} \text { of epidural } \\
\text { prednisolone acetate. } \\
\text { Control: } 125 \mathrm{mg} \text { of } \\
\text { epidural prednisolone. } \\
\text { Frequency: each of the } 3 \\
\text { treatments were provided } \\
\text { once a month for } 3 \\
\text { consecutive mos. }\end{array}$ & $\begin{array}{l}\text { Timing: day } 1 \text {, day } 30 \text {, } \\
\text { and day } 120 . \\
\text { Outcome measures: } \\
\text { Visual Analog Scale. }\end{array}$ & $\begin{array}{l}\text { The VAS scores } \\
\text { improved steadily in } \\
\text { the forceful injection } \\
\text { group, producing } \\
\text { a nonsignificant } \\
\text { difference on day } 120 \\
\text { as compared to the } \\
\text { baseline (day } 30=120 \\
\text { days). }\end{array}$ & $\begin{array}{l}\text { Negative short- } \\
\text { term and long- } \\
\text { term relief. }\end{array}$ \\
\hline
\end{tabular}


Table 8. Characteristics of results of prospective studies of caudal epidural injections.

\begin{tabular}{|c|c|c|c|c|c|}
\hline Study/Methods & Participants & Intervention(s) & Outcome(s) & Result(s) & $\begin{array}{c}\text { Conclusion(s) } \\
\text { Short-term } \\
\text { relief }<6 \mathrm{wks} \\
\text { Long-term } \\
\text { relief }>6 \mathrm{wks}\end{array}$ \\
\hline $\begin{array}{l}\text { Yates }(219) \\
\text { Prospective } \\
\text { evaluation } \\
\text { AHRQ score: } 5 / 8\end{array}$ & $\begin{array}{l}20 \text { pts with low } \\
\text { back pain and } \\
\text { sciatica. }\end{array}$ & $\begin{array}{l}\text { Group I: } 60 \mathrm{mg} \text { of } \\
\text { triamcinolone ( } 3 \mathrm{~mL}+ \\
47 \mathrm{~mL} \text { normal saline). } \\
\text { Group II: } 60 \mathrm{mg} \text { of } \\
\text { triamcinolone }(3 \mathrm{~mL}+ \\
47 \mathrm{~mL} \text { lignocaine } 0.5 \%) \text {. } \\
\text { Group III: } 50 \mathrm{~mL} \text { saline. } \\
\text { Group IV: } 50 \mathrm{~mL} \\
\text { lignocaine injections } \\
\text { given at weekly intervals } \\
\text { in random order. }\end{array}$ & $\begin{array}{l}\text { Timing not } \\
\text { mentioned. Subjective } \\
\text { and objective } \\
\text { criteria of progress. } \\
\text { Did not address } \\
\text { pain-relief, focused } \\
\text { on improvement in } \\
\text { straight leg raising } \\
\text { which seemed to } \\
\text { correlate with pain- } \\
\text { relief. }\end{array}$ & $\begin{array}{l}\text { Greatest improvement } \\
\text { was noted after the } \\
\text { injection-containing } \\
\text { steroid. The results } \\
\text { suggested that the action } \\
\text { of a successful epidural } \\
\text { injection is primarily } \\
\text { anti-inflammatory } \\
\text { and to a lesser extent, } \\
\text { hydrodynamic. }\end{array}$ & $\begin{array}{l}\text { Positive } \\
\text { short-term } \\
\text { and long-term } \\
\text { relief }\end{array}$ \\
\hline $\begin{array}{l}\text { Waldman }(220) \\
\text { Prospective } \\
\text { evaluation with } \\
\text { independent } \\
\text { observer review } \\
\text { AHRQ score: } 5 / 8\end{array}$ & $\begin{array}{l}53 \text { pts meeting } \\
\text { stringent inclusion } \\
\text { criteria with } \\
\text { radicular pain } \\
\text { distribution } \\
\text { anatomically } \\
\text { correlating with } \\
\text { documented } \\
\text { disc herniation } \\
\text { and nerve root } \\
\text { impingement. }\end{array}$ & $\begin{array}{l}\text { Treatment: } 7.5 \mathrm{~mL} \text { of } \\
1 \% \text { lidocaine and } 80 \mathrm{mg} \\
\text { of methylprednisolone } \\
\text { with the first block } \\
\text { and } 40 \mathrm{mg} \text { of methyl- } \\
\text { prednisolone with } \\
\text { subsequent blocks, } \\
\text { which were repeated in } \\
48 \text { - to } 72 \text {-hour intervals } \\
\text { with the end point being } \\
\text { complete pain relief or } 4 \\
\text { caudal epidural blocks. }\end{array}$ & $\begin{array}{l}\text { Timing: } 6 \text { wks, } 3 \\
\text { mos, and } 6 \text { mos. } \\
\text { Visual Analog Scale } \\
\text { and Verbal Analog } \\
\text { Scores. }\end{array}$ & $\begin{array}{l}\text { Combined Visual Analog } \\
\text { Scale and Verbal Analog } \\
\text { Scores for all pts were } \\
\text { reduced } 63 \% \text { at } 6 \text { wks, } \\
67 \% \text { at } 3 \text { mos, and } 71 \% \text { at } \\
6 \text { mos. }\end{array}$ & $\begin{array}{l}\text { Positive } \\
\text { short-term } \\
\text { and long-term } \\
\text { relief }\end{array}$ \\
\hline $\begin{array}{l}\text { Manchikanti et al } \\
(217) \\
\text { Randomized trial } \\
\text { with convenient } \\
\text { control group. } \\
\text { AHRQ score: } 5 / 10\end{array}$ & $\begin{array}{l}70 \text { pts after failed } \\
\text { conservative } \\
\text { management with } \\
\text { physical therapy, } \\
\text { chiropractic, } \\
\text { and medication } \\
\text { therapy. All pts } \\
\text { were shown to be } \\
\text { negative for facet } \\
\text { joint pain. }\end{array}$ & $\begin{array}{l}\text { Group I : no treatment } \\
\text { Group II: local } \\
\text { anesthetic and Sarapin } \\
\text { total of } 20 \mathrm{~mL} \text { with } 10 \\
\text { mL each. } \\
\text { Group III: } 10 \mathrm{~mL} \text { of } \\
\text { local anesthetic and } 6 \\
\text { mg of betamethasone. }\end{array}$ & $\begin{array}{l}\text { Timing: } 2 \text { wks, } 1 \\
\text { month, } 3 \text { mos, } 6 \\
\text { mos, and } 1 \text { year. } \\
\text { Outcome measures: } \\
\text { Average pain, } \\
\text { physical health, } \\
\text { mental health, and } \\
\text { functional status. }\end{array}$ & $\begin{array}{l}\text { Average pain, physical } \\
\text { health, mental health, } \\
\text { functional status, narcotic } \\
\text { intake, and employment } \\
\text { improved significantly in } \\
\text { Group II and Group III at } \\
2 \text { wks, } 1 \text { month, } 3 \text { mos, } 6 \\
\text { mos, and } 1 \text { year. }\end{array}$ & $\begin{array}{l}\text { Positive } \\
\text { short-term } \\
\text { and long-term } \\
\text { relief }\end{array}$ \\
\hline $\begin{array}{l}\text { Manchikanti et al } \\
(218) \\
\text { Prospective } \\
\text { evaluation } \\
\text { AHRQ score: } 5 / 8\end{array}$ & $\begin{array}{l}62 \text { pts evaluated. } \\
\text { Negative } \\
\text { provocative } \\
\text { discography: } 45 \\
\text { pts. } \\
\text { Positive } \\
\text { provocative } \\
\text { discography: } 17 \\
\text { pts. }\end{array}$ & $\begin{array}{l}\text { Caudal epidural } \\
\text { injections (1-3) with or } \\
\text { without steroids. }\end{array}$ & $\begin{array}{l}\text { Timing: } 1 \text { month, } 3 \\
\text { mos, and } 6 \text { mos. } \\
\text { Outcome: average } \\
\text { pain, functional } \\
\text { status, psychological } \\
\text { status, narcotic } \\
\text { intake, and } \\
\text { employment status. }\end{array}$ & $\begin{array}{l}69 \% \text { of the pts in the } \\
\text { negative discography } \\
\text { group and } 65 \% \text { of } \\
\text { the pts in the positive } \\
\text { discography group were } \\
\text { in successful category. }\end{array}$ & $\begin{array}{l}\text { Positive } \\
\text { short-term } \\
\text { and long-term } \\
\text { relief }\end{array}$ \\
\hline $\begin{array}{l}\text { Ciocon et al (221) } \\
\text { Prospective } \\
\text { evaluation in } \\
\text { elderly pts } \\
\text { AHRQ score: } 5 / 8\end{array}$ & $\begin{array}{l}30 \text { pts with spinal } \\
\text { stenosis. }\end{array}$ & $\begin{array}{l}\text { A series of } 3 \text { caudal } \\
\text { epidural steroid } \\
\text { injections, } 0.5 \% \\
\text { xylocaine and } 80 \mathrm{mg} \text { of } \\
\text { Depo-Medrol. }\end{array}$ & $\begin{array}{l}\text { Pain relief, Roland } \\
\text { Morris 5-point } \\
\text { scale. }\end{array}$ & $\begin{array}{l}\text { Duration of pain relief } \\
\text { and improvement ranged } \\
\text { from } 4-10 \text { months. }\end{array}$ & $\begin{array}{l}\text { Positive } \\
\text { short-term } \\
\text { and long-term } \\
\text { relief. }\end{array}$ \\
\hline
\end{tabular}


Patient assessments were carried out before treatment, at 6 weeks, 3 months, and 6 months following treatment. Outcome instruments included SF-MPQ and HAD scores. No significant differences were found between the groups for any of the measures at any time. However, there were significant differences within both groups compared with pretreatment values. For the caudal group, significant improvements were found for descriptive pain at 6 months; VAS at 6 weeks, 3 months, and 6 months; present pain intensity at 3 months and 6 months; anxiety at 6 weeks, 3 months, and 6 months; and depression at 6 months only. Caudal epidural was better than the epiduroscopy group where there were fewer significant changes.

\section{Effectiveness}

Of the 8 randomized trials, 5 were positive for short-term pain relief $(207,209,210,214,215)$, and 4 were positive for long-term relief $(207,209$, 211,214).

Among 8 randomized trials included for analysis, of the 6 trials $(99,207,209-211,214)$ evaluating predominantly radiculopathy, 4 studies were positive $(207,209,210,214)$ and 2 were negative $(99,211)$ for short-term relief, whereas $4(207,209,211,214)$ of 6 $(99,207,209-211,214)$ were positive for long-term relief. Of the 2 studies with postlumbar laminectomy syndrome $(215,216)$, only one study $(215)$ was positive for short-term. One study (214) included patients with sciatica, as well as post lumbar laminectomy syndrome. This study showed positive results, both for short-term and long-term.

Among the 5 prospective studies (217-221), 2 studies evaluating radiculopathy or sciatica $(219,220)$ and 2 studies evaluating the effectiveness of caudal epidural steroid injections in chronic low back pain $(217,218)$ were positive, and 1 study evaluating the effectiveness of caudal in lumbar spinal stenosis was positive (221).

Thus, positive long-term relief trials were $71 \%$ for radiculopathy or sciatica and $67 \%$ for postlumbar laminectomy syndrome. Among the prospective evaluations, $80 \%$ were positive for radiculopathy and chronic low back pain.

\section{Cost Effectiveness}

The costeffectiveness of fluoroscopically-directed caudal epidural steroids was $\$ 3,635$ and that of transforaminal steroids was $\$ 2,927$ per year. In a prospective evaluation, the cost for 1-year improvement for quality-of-life, was $\$ 2,550$, in patients treated with caudal epidural with local anesthetic and Sarapin or steroids under fluoroscopy $(85,217)$.

\section{Level of Evidence}

The evidence of caudal epidural steroid injections with randomized trials and non-randomized reports is strong for short-term relief and moderate for long-term relief in managing chronic pain of lumbar radiculopathy and postlumbar laminectomy syndrome. The evidence is moderate in managing chronic low back pain for short-term and long-term improvement.

\section{Complications}

The most common and worrisome complications of caudal, interlaminar, and transforaminal epidural injections are of 2 types: those related to the needle placement and those related to drug administration. Complications include dural puncture, spinal cord trauma, infection, hematoma formation, abscess formation, subdural injection, intracranial air injection, epidural lipomatosis, pneumothorax, nerve damage, headache, death, brain damage, increased intracranial pressure, intravascular injection, vascular injury, cerebral vascular or pulmonary embolus, and effects of steroids (228291). Spinal cord trauma, and spinal cord or epidural hematoma formation is a catastrophic complication that is rarely seen following interventional procedures in the cervical spine, thoracic spine, or upper lumbar spine.

Botwin et al (225-228) evaluated complications of fluoroscopically-guided epidural steroid injections. Botwin et al (225) reported complications in 207 patients receiving 322 injections of transforaminal lumbar epidural injections. Complications included transient headaches $(3.1 \%)$, increased back pain $(2.4 \%)$, increased leg pain $(0.6 \%)$, facial flushing $(1.2 \%)$, vasovagal reaction $(0.3 \%)$, increased blood sugar $(0.3 \%)$, and hypertension $(0.3 \%)$. The incidence of minor complications was $9.6 \%$ per injection with no major complications.

Botwin et al (226) reported complications of fluoroscopically-guided interlaminar cervical epidural injections. They reported 345 injections in 157 patients. Complications per injection included increased neck pain $(6.7 \%)$, non-positional headaches $(4.6 \%)$, insomnia the night of injection (1.7\%), vasovagal reactions $(1.7 \%)$, facial flushing $(1.5 \%)$, fever the night of the procedure $(0.3 \%)$, and dural puncture $(0.3 \%)$. The incidence of all complications per injection was $16.8 \%$.

Botwin et al (227) also reported adverse effects of fluoroscopically guided interlaminar thoracic epidural steroid injections. A total of 21 patients received 39 injections. Adverse effects or complications per injection observed included pain at injection site $(7.7 \%)$, facial flushing $(5.1 \%)$, transient non-positional head- 
ache $(2.6 \%)$, insomnia the night of injection $(2.6 \%)$, and fever the night of the procedure (2.6\%). No major complications were reported and adverse effects were reported with a rate of $20.5 \%$.

Botwin et al (228) reported complications of fluoroscopically-guided caudal epidural injections in 139 patients, who received 257 injections. Complications per injection included insomnia the night of injection $(4.7 \%)$, transient non-positional headaches $(3.5 \%)$, increased back pain $(3.1 \%)$, facial flushing $(2.3 \%)$, vasovagal reactions $(0.8 \%)$, nausea $(0.8 \%)$, and increased leg pain $(0.4 \%)$. The incidence of minor complications was $15.6 \%$ per injection.

Furman et al (229) evaluated incidence of intravascular penetration in transforaminal lumbosacral epidural steroid injections in a prospective observational study. Among the 761 transforaminal epidural steroid injections included in the study, the overall rate of intravascular injections was $11.2 \%$, with a higher rate of intravascular injections $(21.3 \%)$ noted with transforaminal epidural injections at $\mathbf{S 1}$ compared with those at the lumbar levels (8.1\%).

Furman et al (230) also studied incidence of intravascular penetration in transforaminal cervical epidural steroid injections in 307 patients with 504 treated with transforaminal epidural steroid injections. The overall rate of fluoroscopically-confirmed intravascular contrast injections was $19.4 \%$.

Manchikanti et al (231) reported contrast flow patterns and intravascular needle placement in 100 consecutive patients. Intravenous placement of the needle was noted in $22 \%$ of the procedures. With caudal epidurals, Manchikanti et al (231) reported complications with pain during the injection with back pain in $43 \%$ of the patients and leg pain in $22 \%$ of the patients. They also noted postoperative complications in $34 \%$ of the patients with soreness at injection site in $18 \%$, increased pain in $5 \%$, muscle spasms in $4 \%$, swelling in $4 \%$, headache in $3 \%$, minor bleeding in $2 \%$, dizziness in $1 \%$, nausea and vomiting in $1 \%$, fever in $1 \%$, numbness in $1 \%$, and voiding difficulty in $1 \%$. Manchikanti et al $(232,233)$ reported with fluoroscopically-guided caudal epidural injections intravascular placement in $14 \%$ of the patients. They $(232,233)$ also reported complications in $7 \%$ of the patients with soreness at injection site in $6 \%$, increased pain in $1 \%$, muscle spasms in $1 \%$, headache in $1 \%$, and nausea and vomiting in $1 \%$.

Derby et al (234) surveyed 17 International Spinal Intervention Society (ISIS) instructors who described a total of 5,978 cervical epidurals, interlaminar in 4,389 patients, and transforaminal injections in 1,579 patients. Of the interlaminar injections, there were 23 mild complications $(0.5 \%)$, while there were 5 cases of minor complications in the transforaminal group $(0.32 \%)$.

Transforaminal injections have been the cause of some of the most worrisome recent complications. These included cerebellar and cerebral infarct $(235,247)$, spinal cord injury and infarction $(236,245,249,256)$, massive cerebral edema (237), paraplegia (238), visual defects with occlusion following particulate depo-corticosteroids (239), anterior spinal artery syndrome (240), persistent neurological deficits (241), transient quadriplegia (242), cauda equina syndrome (251), subdural hematoma (253), and paraplegia following intracord injection during attempted epidural anesthesia under general anesthesia (255).

Because of the catastrophes associated with cervical transforaminal epidurals, Huntoon (243) dissected 95 nerve roots in 10 embalmed cadavers. He was able to identify 21 foramina where an artery was noted to be proximal to the posterior aspect of the foraminal opening, confirming the potential for injury to a vessel during transforaminal injections.

Although the complications of cervical spinal injections are devastating, they are fortunately rare. Ma et al (244) reviewed the complications of 1,036 fluoroscopically-guided extraforaminal cervical nerve blocks performed on 844 patients over a 4-year period, and found only 14 patients $(1.66 \%)$ who had even minor complications.

Huston et al (246) reviewed complications of cervical and lumbar selective nerve root injections (SNRs) in 151 consecutive patients who underwent a total of 306 SNRs. There were no major complications noted, and $91 \%$ of the patients had no side effects during the injection. The most common side effect noted was increased pain at the injection site after the injection, which was seen in $17.1 \%$ of the lumbar patients and $22.7 \%$ of the cervical patients.

Paraplegia and quadriplegia have also been reported following interlaminar epidural steroid injections (252).

Infection is occasionally seen with a case of granuloma and intracranial hypertension after 3 cervical epidural steroids (258), thoracic intradural fungal abscess after 3 lumbar epidural steroids $(259,270)$, discitis (267-269,272), and numerous cases of epidural hematoma over the years (262-266).

Other much less common complications include pneumocephalus $(273,275,286)$, transient blindness 
(276), retinol necrosis (277), bilateral cirrus chorioretinopathy $(278,279)$, persistent recurrent intractable hiccups (280), dysphonia (281), flushing (282), arterial gas embolus and cortical blindness $(283,284)$, chemical meningitis (287), retinal hemorrhage (288), radiculopathy (289), nerve root damage (290), and cerebral venous thrombosis (291).

Side effects related to the administration of steroids are generally attributed either to the chemistry or to the pharmacology of the steroids. The major theoretical complications of corticosteroid administration include suppression of pituitary-adrenal axis, hypercorticism, Cushing's syndrome, osteoporosis, avascular necrosis of bone, steroid myopathy, epidural lipomatosis, weight gain, fluid retention, and hyperglycemia. The most commonly used steroids in neural blockade in the United States, methylprednisolone acetate, triamcinolone acetonide, betamethasone acetate, and phosphate mixture have all been shown to be safe at epidural therapeutic doses in both clinical and experimental studies (292-301).

Finally, radiation exposure is also a potential problem with damage to eyes, skin, and gonads (302-304).

\section{Discussion}

This systematic review evaluated and updated the effectiveness of epidural injections in patients with chronic spinal pain. The evidence was evaluated for 3 types of epidurals separately for cervical and lumbar, and for axial, radicular, and postlaminectomy pain.

The previous systematic review arrived at the following conclusions (3). In managing lumbar radicular pain with interlaminar lumbar epidural steroid injections, the level of evidence was strong for short-term relief and limited for long-term relief. In managing cervical radiculopathy with cervical interlaminar epidural steroid injections, the evidence was moderate for short-term improvement and long-term improvement. However, the evidence was indeterminate in management of axial neck pain, axial low back pain, and lumbar spinal stenosis with lumbar or cervical interlaminar epidural steroid injections.

The evidence for lumbar transforaminal epidural steroid injections in managing lumbar nerve root pain was strong with short-term and long-term improvement. The evidence for cervical transforaminal epidural steroid injections in managing cervical nerve root pain was strong with short-term and long-term improvement. The evidence was moderate in managing lumbar radicular pain in postlumbar laminectomy syndrome, with short-term and long-term improvement. The evidence of lumbar transforaminal epidural steroid injections in managing lumbar spinal stenosis was limited. The evidence was indeterminate in managing axial low back pain, axial neck pain, and lumbar disc extrusions.

The evidence of caudal epidural steroid injections with randomized trials and non-randomized reports was strong for short-term relief and moderate for long-term relief, in managing chronic pain of lumbar radiculopathy and postlumbar laminectomy syndrome. The evidence was moderate in managing chronic low back pain for short-term and long-term improvement. The evidence was limited for lumbar spinal stenosis.

The first systematic review of effectiveness of epidural steroid injections was performed by Kepes and Duncalf in 1985 (5). They concluded that the rationale for epidural and systemic steroids was not proven. However, in 1986 Benzon et al (297), utilizing the same studies, concluded that mechanical causes of low back pain, especially those accompanied by signs of nerve root irritation, may respond to epidural steroid injections. The difference in the conclusion of Kepes and Duncalf (5) and Benzon et al (297) may have been due to the fact that Kepes and Duncalf (5) included studies on systemic steroids whereas Benzon (297) limited their analysis to studies on epidural steroid injections only.

The debate concerning epidural steroid injections is also illustrated by the recommendations of the Australian National Health and Medical Research Council Advisory Committee on epidural steroid injections (84). In this report, Bogduk (10) extensively studied caudal, interlaminar, and transforaminal epidural injections, including all the literature available at the time, and concluded that the balance of the published evidence supports the therapeutic use of caudal epidurals. They also concluded that the results of lumbar interlaminar epidural steroids strongly refute the utility of epidural steroids in acute sciatica. Bogduk et al (84) updated their recommendations in 1999, recommending against epidural steroids by the lumbar route because effective treatment required too high a number for successful treatment, but supporting the potential usefulness of transforaminal steroids for disc prolapse. In 1995, Koes et al (6) reviewed 12 trials of lumbar and caudal epidural steroid injections and reported positive results from only 6 studies. However, review of their analysis showed that there were 5 studies for caudal epidural steroid injections and 7 studies for lumbar epidural steroid injections. Four of the 5 studies involving caudal epidural steroid injections were positive, whereas 5 of 7 studies 
Epidural Steroids in the Management of Chronic Spinal Pain

were negative for lumbar epidural steroid injections. Koes et al (7) updated their review of epidural steroid injections for low back pain and sciatica, including 3 more studies with a total of 15 trials which met the inclusion criteria. In this study, they concluded that of the 15 trials, 8 reported positive results of epidural steroid injections. Both reviews mostly reflected the quality of studies, rather than any meaningful conclusion.

Nelemans et al's (8) Cochrane review of injection therapy for subacute and chronic benign low back pain included 21 randomized trials. Of these, 9 were of epidural steroids. They failed to separate caudal from interlaminar epidural injections, but still concluded that convincing evidence is lacking regarding the effects of injection therapy on low back pain. Rozenberg et al (9), in a systematic review, identified 13 trials of epidural steroid therapy. They concluded that 5 trials demonstrated greater pain relief within the first month in the steroid group as compared to the control group. Eight trials found no measurable benefits. They noticed many obstacles for meaningful comparison of cross studies, which included differences in the patient populations, steroid used, volume injected, and number of injections. These authors were unable to determine whether epidural steroids are effective in common low back pain and sciatica based on their review. Rozenburg et al (9) concluded that 3 of the top 5 rated studies did not demonstrate significant benefit of the steroid over the non-steroid group. Hopayiank and Mugford (305) expressed frustration over the conflicting conclusions from two systematic reviews of epidural steroid injections for sciatica and asked which evidence should general practitioners heed. Multiple previous reviews have criticized the studies evaluating the effectiveness of epidural injections. Criticisms ranged from methodology, small size of the study populations, and other limitations, including long-term follow-up and outcome parameters.

Overall the evidence for lumbar interlaminar epidural steroid injections is limited for long-term relief. However, for cervical interlaminar epidural steroid injections, the evidence is moderate. Evidence is indeterminate in management of the axial neck pain, axial low back pain, and lumbar spinal stenosis with lumbar or cervical interlaminar epidural steroid injections.

In this study, the evidence for lumbar transforaminal epidural steroid injections in managing lumbar and cervical nerve root pain is moderate; however, the evidence is limited in managing lumbar radicular pain in postlumbar laminectomy syndrome. The evidence is indeterminate in managing axial low back pain, neck pain, and lumbar disc extrusions.

The evidence of caudal epidural steroid injections is moderate in managing lumbar radiculopathy and postlumbar laminectomy syndrome. In contrast to interlaminar and transforaminal epidural injections the evidence is moderate in managing chronic low back pain. Airaksinen et al (11) in European Guidelines for the Management of Chronic Nonspecific Low Back Pain, published in 2006, which only included the literature up to 2002, concluded that epidural corticosteroid injections would only be considered for radicular pain if it contained disc prolapse as the cause of the pain and if the corticosteroid is injected close to the target or the nerve root. In addition, they also stated that the injection should be fluoroscopically-guided and should aim at the ventral part of the epidural space, near the spinal nerve root or the spinal nerve root through a transforaminal approach. They also concluded that there is conflicting evidence that conventional epidural steroids with a blind approach without fluoroscopic guidance are effective in radicular pain.

The present review is similar to 2 previous systematic reviews and also the guidelines published (16-19). However, it is vastly different from a multitude of other systematic reviews. It is close to European Guidelines for the Management of Chronic Nonspecific Low Back Pain, which advises that fluoroscopically-guided epidurals have better prognosis than the blind epidurals. The present systematic review, similar to the ones performed by Abdi et al (3) and Boswell et al (4), has several additional features.

Finally, all types of epidural steroid injections can be associated with complications and adverse events as described earlier. Therefore attention to detail and caution should be taken when performing any of the 3 techniques discussed in order to improve safety and minimize complications.

This systematic review included multiple new articles not described in the previous reviews.

Arden's study (120) compared $10 \mathrm{~mL}$ of epidural bupivacaine and steroid to $2 \mathrm{~mL}$ normal saline in the interspinous ligament. The use of local anesthetic in one and not the other makes true patient blinding unlikely. Wilson-MacDonald (119) injected the same local and steroid into each patient, either epidurally or in the ligament, but the large volume injected (8 $\mathrm{mL}$ ) would be expected to be very painful and disruptive in the relative closed space of the interspinous ligament, again calling the patient blinding into ques- 
tion. Therefore no significant new information can be gathered from these 2 studies. They also published 2 different manuscripts from 1 study.

In the 2 new cervical transforaminal studies, Kolstad et al (174) and Line et al (130) both showed that cervical epidural transforaminal injections can lead to pain relief significant enough to prevent patients from having to undergo surgery. Yang et al (175) also concluded that lumbar transforaminal injections reduce the need for lumbar surgical decompression.

One could argue that scientific evidence supporting the efficacy of transforaminal epidural steroid injection indirectly supports the efficacy of epidural administration by any route of administration. This argument makes sense in view of the anatomy of the epidural space and the pathophysiology of radiculopathy. To elaborate, the epidural space is a continuous anatomic compartment extending from the base of the skull to the sacrum that can be entered at various levels and by various routes to achieve the same end. The space itself consists of adipose tissue interspersed with random bands of fibrous tissue and venous vessels. The ventral epidural space is closest to the posterior disc margin and the traversing nerve root, which is the presumed site of pathology in lumbar radiculopathy. Although the most direct method to deposit medication into this region is by using a transforaminal approach to needle insertion, it is conceivable that medication may reach this target equally well using a caudal, interlaminar, or catheter route of administration.

Regarding pathophysiology, investigations into the biochemistry of disc degeneration and herniation indicate that intraspinal inflammation is a major cause of radicular pain $(253,255-257,272,283,284)$. The neurotoxic, inflammatory mediator phospholipase A2 (PLA2) is contained within the disc nucleus and is released after annular injury. PLA2 in turn triggers the arachidonic acid cascade, leading to localized inflammation mediated by prostaglandins and leukotrienes. Inflammatory neuropeptides such as calcitonin gene-related peptide (CGrP) and substance $P$ are contained within the dorsal root ganglion and perpetuate inflammation as they are released from irritated nerve roots. Corticosteroids have powerful anti-inflammatory effects, which include inhibition of prostaglandin synthesis, blockade of PLA2 activity, and stabilization of inflammatory cell membranes. Injecting corticosteroids into the epidural space should result in higher concentrations of the active medication at the site of inflammation when compared to oral or parenteral routes of steroid administration. The spinal injection route of administration is the only method of drug delivery that does not rely on blood flow to deliver the medication to its site of action and blood flow may be impaired in the region of compressive disc herniation. Even with normal spinal circulation, blood flow delivers steroid preferentially to high blood flow organs with presumably low concentrations arriving at the site of spinal pathology.

\section{References}

1. Manchikanti L. Medicare in interventional pain management: a critical analysis. Pain Physician 2006; 9:171198.

2. Specialty utilization data files from CMS available at: http://www.cms. hhs.gov/physicians/pfs.

3. Abdi S, Lucas LF, Datta S. Role of epidural steroids in the management of chronic spinal pain: a systematic review of effectiveness and complications. Pain Physician 2005; 8:127-143.

4. Boswell M, Hansen $H$, Trescot $A$, Hirsch J. Epidural steroids in the management of chronic spinal pain and radiculopathy. Pain Physician 2003; 6:319-334.

5. Kepes ER, Duncalf D. Treatment of backache with spinal injections of local anesthetics, spinal and systemic steroids. Pain 1985; 22:33-47.

6. Koes BW, Scholten RJ, Mens JM, Bouter LM. Efficacy of epidural steroid injec- tions for low back pain and sciatica: a systematic review of randomized clinical trials. Pain 1995; 63:279-288.

7. Koes BW, Scholten RJ, Mens JMA, Bouter LM. Epidural steroid injections for low back pain and sciatica: an updated systematic review of randomized clinical trials. Pain Digest 1999; 9:241-247.

8. Nelemans PJ, deBie RA, deVet HC, Sturmans $F$. Injection therapy for subacute and chronic benign low back pain. Spine 2001; 26:501-515.

9. Rozenberg S, Dubourg G, Khalifa P, Paolozzi L, Maheu E, Ravaud P. Efficacy of epidural steroids in low back pain and sciatica: a critical appraisal by a French task force of randomized trials. Revue du Rhumatisme 1999; 66:79-85.

10. Bogduk N. Epidural steroids for low back pain and sciatica. Pain Digest 1999; 9:226-227.

11. Airaksinen O, Brox JI, Cedraschi C, Hildebrandt J, Klaber-Moffett J, Kovacs F, Mannion AF, Reis S, Staal JB, Ur- $\sin \mathrm{H}$ and Zanoli G. Chapter 4: European guidelines for the management of chronic nonspecific low back pain. Eur Spine J 2006; 15:S192-S300.

12. Cannon DT, April CN. Lumbosacral epidural steroid injections. Arch Phys Med Rehabil 2000; 83:S87-S98.

13. McQuay HJ, Moore RA, Eccleston C, Morley S, Williams AC. Systematic review of outpatient services for chronic pain control. Health Technol Assess 1997; 1:1-135.

14. Tonkovich-Quaranta LA, Winkler SR. Use of epidural corticosteroids in low back pain. Ann Pharmacother 2000; 34:11651172.

15. Watts RW, Silagy CA. A meta-analysis on the efficacy of epidural corticosteroids in the treatment of sciatica. Anaesth Intensive Care 1995; 23:564-569.

16. Boswell MV, Shah RV, Everett CR, Sehgal N, Mckenzie-Brown AM, Abdi S, Bowman RC, Deer TR, Datta S, Colson JD, Spillane WF, Smith HS, Lucas-Levin 
LF, Burton AW, Chopra P, Staats PS, Wasserman RA, Manchikanti L. Interventional techniques in the management of chronic spinal pain: evidencebased practice guidelines. Pain Physician 2005; 8:1-47.

17. Manchikanti L, Staats PS, Singh V, Schultz DM, Vilims BD, Jasper JF, Kloth DS, Trescot AM, Hansen HC, Falasca TD, Racz GB, Deer T, Burton AW, Helm S, Lou L, Bakhit CE, Dunbar EE, Atluri SL, Calodney AK, Hassenbusch S, Feler CA. Evidence-based practice guidelines for interventional techniques in the management of chronic spinal pain. Pain Physician 2003; 6:3-80.

18. Manchikanti L, Singh V, Kloth DS, Slipman CW, Jasper JF, Trescot AM, Varley KG, Atluri SL, Giron C, Curran MJ, Rivera JJ, Baha $A$, Bakhit CE, Reuter $M$. Interventional techniques in the management of chronic pain: part 2.0. Pain Physician 2001; 4:24-96.

19. Manchikanti L, Singh V, Bakhit CE, Fellows B. Interventional techniques in the management of chronic pain: part 1.0. Pain Physician 2000; 3:7-42.

20. Verhaak PF, Kerssens JJ, Dekker J, Sorbi MJ, Bensing JM. Prevalence of chronic benign pain disorder among adults: a review of the literature. Pain 1998; 77:231-239.

21. Elliott AM, Smith BH, Hannaford PC, Smith WC, Chambers WA. The course of chronic pain in the community: results of a 4-year follow-up study. Pain 2002; 99:299-307.

22. Lawrence RC, Helmick CG, Arnett FC. Estimates of the prevalence of arthritis and selected musculoskeletal disorders in the United States. Arthritis Rheum 1998; 41:778-799.

23. Cassidy JD, Carroll LJ, Cotê P. The Saskatchewan Health and Back Pain Survey: the prevalence of low back pain and related disability in Saskatchewan adults. Spine 1998; 23:1860-1867.

24. Guo HR, Tanaka S, Halperin WE, Cameron LL. Back pain prevalence in US industry and estimates of lost workdays. Am J Public Health 1999; 89:10291035.

25. Côté P, Cassidy JD, Carroll L. The Saskatchewan Health and Back Pain Survey. The prevalence of neck pain and related disability in Saskatchewan adults. Spine 1998; 23:1689-1698.

26. Linton SJ, Hellsing AL, Hallden K. A population based study of spinal pain among 35-45-year old individuals. Spine 1998, 23:1457-1463.

27. Miemelainen R, Videman T, Battie MC.
Prevalence and characteristics of upper or mid-back pain in Finnish men. Spine 2006; 31:1846-1849.

28. Walker BF, Muller R, Grant WD. Low back pain in Australian adults: prevalence and associated disability. J Manip Physiol Ther 2004; 27:238-244.

29. Bot SD, van der Waal JM, Terwee CB, van der Windt DA, Schellevis FG, Bouter LM, Dekker J. Incidence and prevalence of complaints of the neck and upper extremity in general practice. Ann Rheum Dis 2005; 64:118-123.

30. Bressler HB, Keyes WJ, Rochon PA, Badley $E$. The prevalence of low back pain in the elderly. A systemic review of the literature. Spine 1999; 24:1813-1819.

31. Cecchi F, Debolini P, Lova RM, Macchi C, Bandinelli S, Bartali B, Lauretani F, Benvenuti E, Hicks G, Ferrucci L. Epidemiology of back pain in a representative cohort of Italian persons 65 years of age and older: the InCHIANTI study. Spine 2006; 31:1149-1155.

32. Mortimer M, Pernold G, Wiktorin C. Low back pain in a general population. Natural course and influence of physical exercise--a 5-year follow-up of the Musculoskeletal Intervention CenterNorrtalje Study. Spine 2006; 31:30453051.

33. Cassidy JD, Cote P, Carroll LJ, Kristman V. Incidence and course of low back pain episodes in the general population. Spine 2005; 30:2817-2823.

34. Hestbaek L, Leboeuf-Yde C, Manniche C. Low back pain: what is the long-term course? A review of studies of general patient populations. Eur Spine J 2003; 12:149-165.

35. Croft PR, Lewis M, Papageorgiou AC, Thomas E, Jayson MI, Macfarlane GJ, Silman AJ. Risk factors for neck pain: a longitudinal study in the general population. Pain 2001; 93:317-325.

36. Côté P, Cassidy JD, Carroll LJ, Kristman $V$. The annual incidence and course of neck pain in the general population: a population-based cohort study. Pain 2004; 112:267-273.

37. Enthoven P, Skargren E, Oberg B. Clinical course in patients seeking primary care for back or neck pain: a prospective 5-year follow-up of outcome and health care consumption with subgroup analysis. Spine 2004; 29:2458 2465.

38. Elder LA, Burdorf A. Prevalence, incidence, and recurrence of low back pain in scaffolders during a 3-year follow-up study. Spine 2004; 29:E101-E106.

39. Croft PR, Papageorgiou AC, Thomas E,
Macfarlane GJ, Silman AJ. Short-term physical risk factors for new episodes of low back pain. Prospective evidence from the South Manchester Back Pain Study. Spine 1999; 24:1556-1561.

40. Miedema HS, Chorus AM, Wevers CW, van der Linden S. Chronicity of back problems during working life. Spine 1998; 23:2021-2028.

41. Thomas E, Silman AJ, Croft PR, Papageorgiou AC, Jayson MI, Macfarlane GJ. Predicting who develops chronic low back pain in primary care: a prospective study. Brit Med J 1999; 318:1662-1667.

42. Jackson JL, Passamonti M. The outcomes among patients presenting in primary care with a physical symptom at 5 years. J Gen Intern Med 2005; 20:1032-1037.

43. Jones GT, Johnson RE, Wiles NJ, Chaddock C, Potter RG, Roberts C, Symmons DP, Macfarlane GJ. Predicting persistent disabling low back pain in general practice: a prospective cohort study. $\mathrm{Br}$ J Gen Pract 2006; 56:334-341.

44. Kaaria S, Luukkonen R, Riihimaki $\mathrm{H}$, Kirjonen J, Leino-Arjas P. Persistence of low back pain reporting among a cohort of employees in a metal corporation: A study with 5-, 10-, and 28-year follow-ups. Pain 2006; 120:131-137.

45. Leboeuf-Yde C, Gronstvedt A, Borge JA, Lothe J, Magnesen E, Nilsson O, Rosok G, Stig LC, Larsen K. The Nordic back pain subpopulation program: a 1-year prospective multicenter study of outcomes of persistent low-back pain in chiropractic patients. I Manipulative Physiol Ther 2005; 28:90-96.

46. Kadam UT, Thomas E, Croft PR. Is chronic widespread pain a predictor of allcause morbidity? A 3 year prospective population based study in family practice. J Rheumatol 2005; 32:1341-1348.

47. Kovacs $F M$, Fernández $C$, Cordero $A$, Muriel A, Gonzalez-Lujan L, Gil del Real MT. Spanish Back Pain Research Network. Non-specific low back pain in primary care in the Spanish National Health Service: a prospective study on clinical outcomes and determinants of management. BMC Health Serv Res 2006; 6:57.

48. Saastamoinen $P$, Leino-Arjas $P$, Laaksonen M, Lahelma E. Socio-economic differences in the prevalence of acute, chronic and disabling chronic pain among ageing employees. Pain 2005; 114:364-371.

49. Bunketorp L, Stener-Victorin E, Carlsson J. Neck pain and disability following motor vehicle accidents: a cohort 
study. Eur Spine J 2005; 14:84-89.

50. Frank AO, De Souza LH, Frank CA. Neck pain and disability: a cross-sectiona survey of the demographic and clinical characteristics of neck pain seen in a rheumatology clinic. Int I Clin Pract 2005; 59:173-182.

51. Hartvigsen J, Frederiksen H, Christensen K. Physical and mental function and incident low back pain in seniors: a population-based two-year prospective study of 1387 Danish Twins aged 70 to 100 years. Spine 2006; 31:1628-1632.

52. Jacob T. Low back pain incident episodes: a community-based study. Spine J 2006; 6:306-310.

53. Weiner DK, Kim YS, Bonino P, Wang T. Low back pain in older adults: are we utilizing healthcare resources wisely? Pain Med 2006; 7:143-150.

54. Ekman M, Jönhagen S, Hunsche E, Jonsson L. Burden of illness of chronic low back pain in Sweden: a cross-sectional, retrospective study in primary care setting. Spine 2005; 30:1777-1785.

55. Ritzwoller DP, Crounse L, Shetterly S, Rublee D. The association of comorbidities, utilization and costs for patients identified with low back pain. $B M C$ Musculoskelet Disord 2006; 7:72.

56. Vogt MT, Kwoh CK, Cope DK, Osial TA, Culyba M, Starz TW. Analgesic usage for low back pain: impact on health care costs and service use. Spine 2005; 30:1075-1081.

57. Ricci JA, Stewart WF, Chee E, Leotta C, Foley K, Hochberg MC. Back pain exacerbations and lost productive time costs in United States workers. Spine 2006; 31:3052-3060.

58. White AG, Birnbaum HG, Mareva MN, Daher M, Vallow S, Schein J, Katz N. Direct costs of opioid abuse in an insured population in the United States. J Manag Care Pharm 2005; 11:469-479.

59. Luo X, Pietrobon R, Sun SX, Liu GG, Hey L. Estimates and patterns of direct health care expenditures among individuals with back pain in the United States. Spine 2004; 29:79-86.

6o. Leigh JP, Markowitz SB, Fahs M, Shin C, Landrigan PJ. Occupational injury and illness in the United States. Estimates of costs, morbidity, and mortality. Arch Intern Med 1997; 157:1557-1568.

61. Freedman VA, Martin LG, Schoeni RF. Recent trends in disability and functioning among older adults in the united states. JAMA 2002; 288:3137-3146.

62. Hurwitz EL, Morgenstern H, Yu F. Crosssectional and longitudinal associations of low-back pain and related disabili- ty with psychological distress among patients enrolled in the UCLA LowBack Pain Study. J Clin Epidemiol 2003; 56:463-471.

63. Maetzel A, Li L. The economic burden of low back pain: a review of studies published between 1996 and 2001. Best Pract Res Clin Rheumatol 2002; 16:23-30.

64. Bell G, Kidd D, North R. Cost-effectiveness analysis of spinal cord stimula tion in treatment of failed back surgery syndrome. J Pain Symp Manage 1997; 13:286-295.

65. de Lissovoy G, Brown RE, Halpern M, Hassenbusch SJ, Ross E. Cost-effectiveness of long-term intrathecal morphine therapy for pain associated with failed back surgery syndrome. Clin Ther 1997; 19:96-112.

66. Macario A, Pergolizzi JV. Systematic literature review of spinal decompression via motorized traction for chronic discogenic low back pain. Spine 2006; 6:171-178.

67. Murtagh J, Foerster V. Radiofrequency neurotomy for lumbar pain [Issues in emerging health technologies, issue 83]. Ottawa: Canadian Agency for Drugs and Technologies in Health; 2006.

68. Khadilkar A, Milne S, Brosseau L, Robinson V, Saginur M, Shea B, Tugwell P, Wells G. Transcutaneous electrical nerve stimulation (TENS) for chronic low-back pain. Cochrane Database Syst Rev 2005; 3:CDo03008.

69. French SD, Cameron M, Walker BF, Reggars JW, Esterman AJ. A Cochrane review of superficial heat or cold for low back pain. Spine 2006; 31:998-1006.

70. Clarke JA, van Tulder MW, Blomberg SE, de Vet HC, van der Heijden GJ, Bronfort $\mathrm{G}$. Traction for low-back pain with or without sciatica. Cochrane Database Syst Rev 2005; 4:CDo03010.

71. Kay TM, Gross A, Goldsmith C, Santaguida PL, Hoving J, Bronfort G, Cervical Overview Group. Exercises for mechanical neck disorders. Cochrane Database Syst Rev 2005; 3:CDoo4250.

72. Chow RT, Barnsley L. Systematic review of the literature of low-level laser therapy (LLLT) in the management of neck pain. Laser Surg Med 2005; 37:46-52.

73. Singh K, Ledet E, Carl A. Intradiscal therapy: a review of current treatment modalities. Spine 2005; 30:S20-S26.

74. Taylor RS, Taylor RJ, Fritzell P. Balloon kyphoplasty and vertebroplasty for vertebral compression fractures: a comparative systematic review of efficacy and safety. Spine 2006; 31:2747-2755.
75. Gibson JN, Waddell G. Surgery for degenerative lumbar spondylosis: updated Cochrane Review. Spine 2005; 30:2312-2320.

76. Weinstein JN, Tosteson TD, Lurie JD, Tosteson AN, Hanscom B, Skinner JS, Abdu WA, Hilibrand AS, Boden SD, Deyo RA. Surgical vs nonoperative treatment for lumbar disk herniation: the Spine Patient Outcomes Research Trial (SPORT): a randomized trial. JAMA 2006; 296:2441-2450.

77. Schofferman J, Reynolds J, Herzog R, Covington E, Dreyfuss P, O'Neill C. Failed back surgery: etiology and diagnostic evaluation. Spine J 2003; 3:400-403.

78. Slipman CW, Shin $\mathrm{CH}$, Patel RK, Isaac Z, Huston CW, Lipetz JS, Lenrow DA, Braverman DL, Vresilovic EJ Jr. Etiologies of failed back surgery syndrome. Pain Med 2002; 3:200-214.

79. Waguespack A, Schofferman J, Slosar $P$, Reynolds J. Etiology of long-term failures of lumbar spine surgery. Pain Med 2002; 3:18-22.

8o. Boden S, Bohlman H. The Failed Spine. Lippincott, Williams \& Wilkins, Philadelphia, PA, 2003.

81. Sampath P, Bendebba M, Davis JD, Ducker T. Outcome in patients with cervical radiculopathy. Prospective, multicenter study with independent clinical review. Spine 1999; 24:591-597.

82. Law JD, Lehman RAW, Kirsch WM. Reoperation after lumbar intervertebral disc surgery. J Neurosurg 1978; 48:259263.

83. Waddell G, Kummel EG, Lotto WN, Graham JD, Hall H, McCulloch JA. Failed lumbar disc surgery and repeat surgery following industrial injury. J Bone Joint Surg (Am) 1979; 61:201-207.

84. Bogduk N, Christophidis N, Cherry D. Epidural use of steroids in the management of back pain. Report of working party on epidural use of steroids in the management of back pain. National Health and Medical Research Council. Canberra, Commonwealth of Australia, 1994, pp 1-76.

85. Manchikanti L, Pakanati RR, Pampati V. Comparison of three routes of epidural steroid injections in low back pain. Pain Digest 1999; 9:277-285.

86. Byrod G, Otani K, Brisby H, Rydevik B, Olmarker K. Methylprednisolone reduces the early vascular permeability increase in spinal nerve roots induced by epidural nucleus pulposus application. J Orthop Res 2000; 18:983-987.

87. Flower RJ, Blackwell GJ. Anti-inflammatory steroid induced biosynthesis of a 
phospholipase A2 inhibitor which prevents prostaglandin generation. Nature 1979; 278:456-459.

88. Lundin A, Magnuson A, Axelsson K, Nilsson O, Samuelsson L. Corticosteroids preoperatively diminishes damage to the C-fibers in microscopic lumbar disc surgery. Spine 2005; 30:2362-2367.

89. Nicol GD, Klingberg DK, Vasko MR. Prostaglandin E2 enhances calcium conductance and stimulates release of substance $P$ in avian sensory neurons. J Neurosci 1992; 12:1917-1927.

90. Hua SY, Chen YZ. Membrane receptormediated electrophysiological effects of glucocorticoid on mammalian neurons. Endocrinology 1989; 124:687-691.

91. Hayashi N, Weinstein JN, Meller ST, Lee HM, Spratt KF, Gebhart GF. The effect of epidural injection of betamethasone or bupivacaine in a rat model of lumbar radiculopathy. Spine 1998; 23:877-885.

92. Lee HM, Weinstein JN, Meller ST, Hayashi N, Spratt KF, Gebhart GF. The role of steroids and their effects on phospholipase A2: an animal model of radiculopathy. Spine 1998; 23:1191-1196.

93. Minamide A, Tamaki T, Hashizume H, Yoshida M, Kawakami M, Hayashi N. Effects of steroids and lipopolysaccharide on spontaneous resorption of herniated intervertebral discs: an experience study in the rabbit. Spine 1998; 23:870-876.

94. Kingery WS, Castellote JM, Maze M. Methylprednisolone prevents the development of autotomy and neuropathic edema in rats, but has no effect on nociceptive thresholds. Pain 1999; 80:555-566.

95. West S, King V, Carey T, Lohr K, McKoy N, Sutton S, Lux L. Systems to rate the strength of scientific evidence. Evidence Report/Technology Assessment No. 47 University of North Carolina: Agency for Healthcare Research and Quality. AHRQ Publication No. 02-E016; April 2002.

96. van Tulder M, Assendelft W, Koes B, Bouter LM. Method guidelines for systematic reviews in the Cochrane Collaboration Back Review Group for Spinal Disorders. Spine 1997; 22:2323-2330.

97. Manchikanti L, Abdi S, Lucas LF. Evidence synthesis and development of guidelines in interventional pain management. Pain Physician 2005; 8:7386.

98. Shekelle PG, Andersson G, Bombardier C, Cherkin D, Deyo R, Keller R, Lee C, Liang $M$, Lipscomb B, Spratt K. A brief introduction to the critical reading of the clinical literature. Spine 1994; 19(suppl):2028S-2031S.

99. McGregor AH, Anjarwalla NK, Stambach T. Does the method of injection alter the outcome of epidural injections? J Spinal Disord 2001; 14:507-510.

100. Carette $S$, Leclaire R, Marcoux S, Morin F, Blaise GA, St-Pierre A, Truchon R, Parent $F$, Levesque J, Bergeron $\mathrm{V}$, Montminy P, Blanchette C. Epidural corticosteroid injections for sciatica due to herniated nucleus pulposus. $N$ Engl I Med 1997; 336:1634-1640.

101. Snoek W, Weber H, Jorgensen B. Double-blind evaluation of extradural methylprednisolone for herniated lumbar disc. Acta Orthop Scand 1977; 48:635-641.

102. Cuckler JM, Bernini PA, Wiesel SW, Booth RE Jr, Rothman RH, Pickens GT. The use of epidural steroid in the treatment of radicular pain. I Bone Joint Surg 1985; 67:63-66.

103. Dilke TF, Burry HC, Grahame R. Extradural corticosteroid injection in the management of lumbar nerve root compression. Br Med J 1973; 2:635-637.

104. Serrao JM, Marks RL, Morley SJ, Goodchild CS. Intrathecal midazolam for the treatment of chronic mechanical low back pain: a controlled comparison with epidural steroid in a pilot study. Pain 1992; 48:5-12.

105. Klenerman L, Greenwood R, Davenport HT, White DC, Peskett S. Lumbar epidural injections in the treatment of sciatica. Br J Rheumatol 1984; 23:35-38.

106. Rocco AG, Frank E, Kaul AF, Lipson SJ, Gallo JP. Epidural steroids, epidural morphine and epidural steroids combined with morphine in the treatment of post-laminectomy syndrome. Pain 1989; 36:297-303.

107. Ridley MG, Kingsley GH, Gibson T, Grahame R. Outpatient lumbar epidural corticosteroid injection in the management of sciatica. Br J Rheumatol 1988; 27:295-299.

108. Rogers P, Nash T, Schiller D and Norman J. Epidural steroids for sciatica. Pain Clinic 1992; 5:67-72.

109. Castagnera L, Maurette P, Pointillart V, Vital JM, Erny P, Senegas J. Long-term results of cervical epidural steroid injection with and without morphine in chronic cervical radicular pain. Pain 1994; 58:239-243.

110. Hernandez R, Lopez F. Assessment of pain intensity in patients with diabetic polyneuropathy treated with peridural $2 \%$ lidocaine methylprednisolone acetate vs peridural $2 \%$ lidocaine. Aneste- sia en Mexico 1999; 11:65-69.

111. Kikuchi A, Kotani N, Sato T, Takamura K, Sakai I, Matsuki A. Comparative therapeutic evaluation of intrathecal versus epidural methylprednisolone for long-term analgesia in patients with intractable postherpetic neuralgia. Reg Anesth Pain Med 1999; 24:287-293.

112. Helliwell M, Robertson JC, Ellia RM. Outpatient treatment of low back pain and sciatica by a single extradural corticosteroid injection. $\mathrm{Br} / \mathrm{Clin}$ Pract 1985; 39:228-231.

113. Stav A, Ovadia L, Sternberg A, Kaadan M, Weksler N. Cervical epidural steroid injection for cervicobrachialgia. Acta Anaesthesiol Scand 1993; 37:562-566.

114. Buchner M, Zeifang F, Brocai DR, Schiltenwolf M. Epidural corticosteroid injection in the conservative management of sciatica. Clin Orth Rel Res 2000; 375:149-156.

115. Valat JP, Giraudeau B, Rozenberg S, Goupille P, Bourgeois P, Micheau-Beaugendre V, Soubrier M, Richard S, Thomas E. Epidural corticosteroid injections for sciatica: a randomised, double blind, controlled clinical trial. Ann Rheum Dis 2003; 62:639-43.

116. Kraemer J, Ludwig J, Bickert U, Owczarek V, Traupe M. Lumbar epidural perineural injection: a new technique. Eur Spine J 1997; 6:357-361.

117. Pirbudak L, Karakurum G Oner U, Gulec A, Karadasli H. Epidural corticosteroid injection and amitriptyline for the treatment of chronic low back pain associated with radiculopathy. Pain Clinic 2003; 15:247-253.

118. Bronfort G, Evans RL, Maiers M, Anderson AV. Spinal manipulation, epidural injections, and self-care for sciatica: a pilot study for a randomized clinical trial. J Manipulative Physiol Ther 2004; 278:503-508.

119. Wilson-MacDonald J, Burt G, Griffin D, Glynn C. Epidural steroid injection for nerve root compression: a randomized, controlled trial. J Bone Joint Surg $\mathrm{Br}$ 2005; 87-B:352-355.

120. Arden NK, Price C, Reading I, Stubbing J, Hazelgrove J, Dunne C, Michel M, Rogers P, Cooper C, WEST Study Group. A multicentre randomized controlled trial of epidural corticosteroid injections for sciatica: the WEST study. Rheumatology (Oxford) 2005; 44:1399-1406.

121. Bush K, Hillier S. Outcome of cervical radiculopathy treated with periradicular/epidural corticosteroid injections: a prospective study with independent clinical review. Eur Spine J 1996; 
5:319-325

122. Rull BM, Miralles M, Aure S. Therapeutic epidural infiltrations in the lumbar nerve roots. Revista de Ortopedia y Traumatologia 1996; 40:209-217.

123. Caglar S, Erdine S, Aldemir T. The results of the epidural steroid injections in patients with radiculopathies due to lumbar disc herniations. Fizik Tedavi Rehabilitasyon Dergisi 1995; 19:186190.

124. Rivest C, Katz JN, Ferrante FM, Jamison RN. Effects of epidural steroid injection on pain due to lumbar spinal stenosis or herniated discs: a prospective study. Arthritis Care Res 1998; 11:291-297.

125. Koning HM, Koning AJ; Bruinen TCM; Koster HG; Heybroek E. The period of pain relief following a successful epidural steroid injection for low back pain. Pain Clinic 2002; 13:331-338.

126. Andersen KH, Mosdal C. Epidural application of corticosteroids in low back pain and sciatica. Acta Neurochir 1987; 87:52-53.

127. Warfield CA, Crews DA. Epidural steroid injection as a predictor of surgical outcome. Surg Gyn Obstet 1987; 164:457458.

128. Fukusaki M, Kobayashi I, Hara T, Sumikawa K. Symptoms of spinal stenosis do not improve after epidural steroid injection. Clin J Pain 1998; 14:148-151.

129. Stav A, Ovadia L, Landau M, Weksler N, Berman M. Epidural steroid injection in the treatment of lumbar and cervical pain syndromes: a preliminary retrospective comparison. Pain Clinic 1991; 4:95-112.

130. Lin EL, Lieu V, Halevi L, Shamie AN, Wang JC. Cervical epidural steroid injections for symptomatic disc herniations. J Spinal Disord Tech 2006; 19:183-186.

131. Mangar D, Thomas PB. Epidural steroid injections in the treatment of cervical and lumbar pain syndromes. Reg Anesth 1991; 16:246.

132. Shulman M. Treatment of neck pain with cervical epidural steroid injection. Reg Anesth 1986; 11:92-94.

133. Catchlove RFH, Braha R. The use of cervical epidural nerve blocks in the management of chronic head and neck pain. Can Anaesth Soc J 1984; 31:188 191.

134. Berman AT, Garbarino JL Jr, Fisher SM, Bosacco SJ. The effects of epidural injection of local anesthetics and corticosteroids in patients with lumbosciatic pain. Clin Orthop 1984; 188:144-151.

135. Purkis IE. Cervical epidural steroids. Pain Clinic 1986; 1:3-7.
136. Rowlingson JC, Kirschenbaum LP. Epidural analgesic techniques in the management of cervical pain. Anesth Analg 1986; 65:938-942.

137. Warfield CA, Biber MP, Crews DA, Dwarakanath,GK. Epidural steroid injection as a treatment for cervical radiculitis. Clin J Pain 1988; 4:201-204.

138. Cicala RS, Thoni K, Angel JJ. Long-term results of cervical epidural steroid injections. Clin J Pain 1989; 5:143-145.

139. Pawl RP, Anderson W, Shulman M. Effect of epidural steroids in the cervical and lumbar region on surgical intervention for discogenic spondylosis. Clin Pain 1985; 1:181-185.

140. Ferrante FM, Wilson SP, lacobo C, Orav EJ, Rocco AG, Lipson S. Clinical classification as a predictor of therapeutic outcome after cervical epidural steroid injection. Spine 1993; 18:730-736.

141. Klein GR, Vaccaro AR, Cwik J, Seitchik S, Viscusi ER, Albert TJ. Efficacy of cervical epidural steroids in the treatment of cervical spine disorders. Am J Anesthesiol 2000; 9:547-552.

142. Ozyalcin S, Yucel A, Erdine S. Epidural steroid injection in the treatment of cervical pain syndromes: a retrospective follow up study. Angri Dergisi 1996; 8:9-14.

143. Hickey RF. Outpatient epidural steroid injections for low back pain and lumbosacral radiculopathy. NZ Med J 1987; 100:54-59.

144. Heyse-Moore GH. A rational approach to the use of epidural medication in the treatment of sciatic pain. Acta Orthop Scand 1978; 49:366-370.

145. Harley C. Extradural corticosteroid infiltration: a follow-up study of 50 cases. Ann Phy Med 1966; 9:22-28.

146. Sharma S, Stedman R. Epidural steroids: a retrospective analysis of the efficacy of high and low dose therapy. Anesthesiology 1998; 3A:A1135.

147. Rosen CD, Kahanovitz N, Bernstein R, Viola K. A retrospective analysis of the efficacy of epidural steroid injections. Clin Orthop 1988; 228:270-272.

148. Arnhoff FN, Triplett HB, Pokorney B. Follow-up status of patients treated with nerve blocks for low back pain. Anesthesiology 1977; 46:170-178.

149. Jamison RN, VadeBoncouer T, Ferrante FM. Low back pain patients unresponsive to an epidural steroid injection: identifying predictive factors. Clin J Pain 1991; 7:311-317.

150. Hopwood MB, Abram SE. Factors associated with failure of lumbar epidural steroids. Reg Anesth 1993; 18:238-
243.

151. Reale C, Turkiewicz AM, Reale CA, Stabile S, Borgonuovo P, Apponi F. Epidural steroids as a pharmacological approach. Clin Exp Rheumatol 2000; 18: S65-S66.

152. Bowman SJ, Wedderburn L, Whaley A, Grahame R, Newman S. Outcome assessment after epidural corticosteroid injection for low back pain and sciatica. Spine 1993; 18:1345-1350.

153. Jurmand SH. Cortiotherapie peridurale des lombalgies et des sciatiques d'origine discale. Concours Medicale 1972; 94:5061-5070.

154. Ito R. The treatment of low back pain and sciatica with epidural corticosteroids injection and its pathophysiologic basis. J Jpn Orthop Assoc 1971; 45:769-777.

155. Brown FW. Management of discogenic pain using epidural and intrathecal steroids. Clin Orthop 1977; 129:72-78.

156. Warr AC, Wilkinson JA, Burn JM, Langdon L. Chronic lumbosciatica syndrome treated by epidural injection and manipulation. Practitioner 1977; 209:53-59.

157. Papagelopoulos PJ, Petrou HG, Triantafyllidis PG, Vlamis JA, Psomas-Pasalis M, Korres DS, Stamos KG. Treatment of lumbosacral radicular pain with epidural steroid injections. Orthopedics 2001; 24:145-149.

158. Silva J, Costa AO, Simoes MT, Neto RR. Management of radicular pain from lumbar herniated disc using betamethasone epidural injection. Revista Brasileira de Ortopedia 1999; 34:165168.

159. Wang JC, Lin E, Brodke DS, Youssef JA. Epidural injections for the treatment of symptomatic lumbar herniated discs. J Spinal Disord Tech 2002; 15:269-272.

160. Price C, Arden N, Coglan L, Rogers P. Cost-effectiveness and safety of epidural steroids in the management of sciatica. Health Technol Assess 2005; 9:158, iii.

161. Schaufele MK, Hatch L, Jones W. Interlaminar versus transforaminal epidural injections for the treatment of symptomatic lumbar intervertebral disc herniations. Pain Physician 2006; 9:361366.

162. Riew KD, Park JB, Cho YS, Gilula L, Patel A, Lenke LG, Bridwell KH. Nerve root blocks in the treatment of lumbar radicular pain: a minimum five-year follow-up. J Bone Joint Surg Am 2006; 88:1722-1725.

163. Ng L, Chaudhary N, Sell P. The efficacy of corticosteroids in periradicular infiltration for chronic radicular pain: a ran- 
domized, double-blind, controlled trial. Spine 2005; 30:857-862.

164. Riew KD, Yin Y, Gilula L, Bridwell KH, Lenke LG, Lauryssen C, Goette K. The effect of nerve-root injections on the need for operative treatment of lumbar radicular pain. J Bone Joint Surg $A M$ 2000; 82: 1589-1593.

165. Karppinen J, Malmivaara A, Kurunlahti M, Kyllonen E, Pienimaki T, Nieminen $P$, Ohinmaa A, Tervonen O, Vanharanta H. Periradicular infiltration for sciatica. Spine 2001; 26:1059-1067.

166. Karppinen J, Ohinmaa A, Malmivaara A, Kurunlahti M, Kyllonen E, Pienimaki T, Nieminen P, Tervonen O, Vanharanta $\mathrm{H}$. Cost effectiveness of periradicular infiltration for sciatica. Spine 2001; 26:2587-2595.

167. Devulder J, Deene P, De Laat M, Van Bastelaere M, Brusselmans G, Rolly G. Nerve root sleeve injections in patients with failed back surgery syndrome: a comparison of three solutions. Clin $J$ Pain 1999; 15:132-135.

168. Kolsi I, Delecrin J, Berthelot JM, Thomas L, Prost A, Maugars Y. Efficacy of nerve root versus interspinous injections of glucocorticoids in the treatment of disc-related sciatica: a pilot, prospective, randomized, double-blind study. Joint Bone Spine 2000; 67:113-118.

169. Vad VB, Bhat AL, Lutz GE, Cammisa F. Transforaminal epidural steroid injections in lumbosacral radiculopathy: a prospective randomized study. Spine 2002; 27:11-16.

170. Thomas E, Cyteval C, Abiad L, Picot MC, Taourel P, Blotman F. Efficacy of transforaminal versus interspinous corticosteroid injection in discal radiculalgia: a prospective, randomised, double-blind study. Clin Rheumatol 2003; 22:299-304.

171. Anderberg L, Annertz M, Persson L, Brandt L, Saveland H. Transforaminal steroid injections for the treatment of cervical radiculopathy: a prospective and randomised study. Eur Spine J 2006; Epub ahead of print.

172. Autio RA, Karppinen J, Niinimaki J, Ojala R, Kurunlahti M, Haapea M, Vanharanta $H$, Tervonen O. Determinants of spontaneous resorption of intervertebral disc herniations. Spine 2006; 31:12471252.

173. Tong HC, Williams JC, Haig AJ, Geisser ME, Chiodo A. Predicting outcomes of transforaminal epidural injections for sciatica. Spine J 2003; 3:430-434.

174. Kolstad F, Leivseth $G$ and Nygaard $O$. Transforaminal steroid injections in the treatment of cervical radiculopathy. A prospective outcome study. Acta Neurochir (Wien) 2005; 147:1065-1070.

175. Yang SC, Fu TS, Lai PL, Niu CC, Chen LH, Chen WJ. Transforaminal epidural steroid injection for discectomy candidates: an outcome study with a minimum of two-year follow-up. Chang Gung Med J 2006; 29:93-99.

176. Ng LC, Sell P. Outcomes of a prospective cohort study on peri-radicular infiltration for radicular pain in patients with lumbar disc herniation and spinal stenosis. Eur Spine J 2004; 13:325-329.

177. Karaeminogullari O, Sahin O, Boyvat $F$, Akgun RC, Gurun U, Demirors H, Tuncay IC, Tandogan RN. Transforaminal epidural steroid injection under computed tomography guidance in relieving lumbosacral radicular pain. Acta Orthop Traumatol Turc 2005; 39:416-420.

178. Michel JL, Lemaire S, Bourbon H, Reynier C, Lhoste A, Soubrier S, Dubost JJ, Ristori JM. Fluoroscopy guided L5-S1 transforaminal injection as a treatment for s1 radiculopathy. I Radiol 2004; 85:1937-1941.

179. Lutz GE, Vad VB, Wisneski RJ. Fluoroscopic transforaminal lumbar epidural steroids: an outcome study. Arch Phys Med Rehabil 1998; 79:1362-1366.

180. Dreyfuss P, Baker R, Bogduk N. Comparative effectiveness of cervical transforaminal injections with particulate and nonparticulate corticosteroid preparations for cervical radicular pain. Pain Med 2006; 7:237-242.

181. Berger O, Dousset V, Delmer O, Pointillart V, Vital JM, Caille JM. Evaluation of the efficacy of foraminal infusions of corticosteroids guided by computed tomography in the treatment of radicular pain by foraminal injection. / Radiol 1999; 80:917-925.

182. Melzer A, Seibel RM. Magnetic resonance (MR)-guided percutaneous pain therapy of degenerative spinal diseases. Semin Interv Radiol 1999; 16:143150.

183. Sequeiros RB, Ojala RO, Klemola R, Vaara TJ, Jyrkinen L, Tervonen OA. MRIguided periradicular nerve root infiltration therapy in low-field (o.23-T) MRI system using optical instrument track ing. Eur Radiol 2002; 12:1331-1337.

184. Zennaro H, Dousset V, Viaud B, Allard M, Dehais J, Senegas J, Caille JM. Periganglionic foraminal steroid injections performed under CT control. Am J Neuroradiol 1998; 19:349-352.

185. Groenemeyer DH, Gevargez A, Schindler O, Schirp S, Braun M. CT- guided periradicular injections of corticosteroids in the management of lumbar radiculopathy associated with disk herniation. J Radiol 2002; 1-12.

186. Buttermann GR. Lumbar disc herniation regression after successful epidural steroid injection. J Spinal Disord Tech 2002; 15:469-476.

187. Buttermann GR. The effect of spinal steroid injections for degenerative disc disease. Spine J 2004; 4:495-505.

188. Buttermann GR. Treatment of lumbar disc herniation: epidural steroid injection compared with discectomy. A prospective, randomized study. I Bone Joint Surg Am 2004; 86-A:670-679.

189. Cyteval C, Thomas E, Decoux E, Sarrabere MP, Cottin A, Blotman F, Taourel P. Cervical radiculopathy: open study on percutaneous periradicular foraminal steroid infiltration performed under CT control in 30 patients. AJNR Am J Neuroradiol 2004; 25:441-445.

190. Botwin KP, Gruber RD, Bouchlas CG, Torres-Ramos FM, Sanelli JT, Freeman $E D$, Slaten WK, Rao S. Fluoroscopically guided lumbar transformational epidural steroid injections in degenerative lumbar stenosis: an outcome study. Am J Phys Med Rehabil 2002; 81:898-905.

191. Lee JW, Kim SH, Lee IS, Choi JA, Choi JY, Hong SH, Kang HS. Therapeutic effect and outcome predictors of sciatica treated using transforaminal epidural steroid injection. AJR Am J Roentgenol 2006; 187:1427-1431.

192. Slipman CW, Lipetz JS, DePalma MJ, Jackson HB. Therapeutic selective nerve root block in the nonsurgical treatment of traumatically induced cervical spondylotic radicular pain. $\mathrm{Am}$ J Phys Med Rehabil 2004; 83:446-454.

193. Slipman C, Lipetz J, Jackson H, Plastaras $\mathrm{C}$, Vresilovic E. Outcomes of therapeutic selective nerve root blocks for whiplash induced cervical radicular pain. Pain Physician 2001; 4:167-174.

194. Lutze M, Stendel R, Vesper J, Brock M. Periradicular therapy in lumbar radicular syndromes: methodology and results. Acta Neurochir 1997; 139:719724.

195. Uhlenbrock D, Arlinghaus J. Results of CT-guided periradicular pain therapy. Rofo 1997; 166:528-534.

196. Le Chevallier PL, Videgrain M, Roulleau P, Delvert JC, Valat JP, Castaing J. Injection of the sacrolumbar roots: a complementary method of staging sciatica. 18 cases. Rev Rhum Mal Osteoartic 1978; 45:473-477.

197. Devulder J. Transforaminal nerve root 
sleeve injection with corticosteroids, hyaluronidase, and local anesthetic in the failed back surgery syndrome. $J$ Spinal Disord 1998; 11:151-154.

198. Weiner BK, Fraser RD. Foraminal injection for lateral lumbar disc herniation. J Bone Joint Surg 1997; 79-B:804-807.

199. Narozny M, Zanetti M, Boos N. Therapeutic efficacy of selective nerve root blocks in the treatment of lumbar radicular leg pain. Swiss Med Wkly 2001; 131:75-80.

200. Friedman R, Li V, Mehrotra D, Mosuro $\mathrm{Y}$, Atkinson $\mathrm{G}$. Foraminal injection of a painful sacral nerve root using an epidural catheter: case report. Reg Anesth Pain Med 2002; 27:214-216.

201. Rosenberg SK, Grabinsky A, Kooser C, Boswell M. Effectiveness of transforaminal epidural steroid injections in low back pain: a one year experience. Pain Physician 2002; 5:266-270.

202. Schmid G, Vetter S, Gottmann D, Strecker EP. CT-guided epidural/perineural injections in painful disorders of the lumbar spine: short- and extendedterm results. Cardiovasc Intervent $\mathrm{Ra}$ diol 1999; 22:493-498.

203. Groenmeyer DH, Seibel R, Schindler O, Schattauer K, Lange S, Schmidt A. Microinvasive CT guided periradicu lar therapy for treatment of chronical functional disorders of the spine. Wein er Medizinische Wochenschrift 1995; 145:129-139.

204. Slipman CW, Lipetz JS, Jackson HB, Rogers DP, Vresilovic EJ. Therapeutic selective nerve root block in the nonsurgical treatment of atraumatic cervical spondylotic radicular pain: a retrospective analysis with independent clinical review. Arch Phys Med Rehabil 2000; 81:741-746.

205. Lee KS, Lin CL, Hwang SL, Howng SL, Wang CK. Transforaminal periradicular infiltration guided by $\mathrm{CT}$ for unilateral sciatica: an outcome study. Clin Imaging 2005; 29:211-214.

206. Sasso RC, Macadaeg K, Nordmann D, Smith M. Selective nerve root injections can predict surgical outcome for lumbar and cervical radiculopathy: comparison to magnetic resonance imaging. J Spinal Disord Tech 2005; 18:471-478.

207. Dashfield AK, Taylor MB, Cleaver JS, Farrow D. Comparison of caudal epidural with targeted steroid placement during spinal endoscopy for chronic sciatica: a prospective, randomized, double-blind trial. Br J Anaesth 2005; 94:514-519.

208. Anwar A, Zaidah I, Rozita R. Prospective randomized single blind study of epidural steroid injection comparing triamcinolone acetonide with methylprednisolone acetate. APLAR / Rheumatology 2005; 8:1-53.

209. Breivik H, Hesla PE, Molnar I, Lind B. Treatment of chronic low back pain and sciatica. Comparison of caudal epidural injections of bupivacaine and methylprednisolone with bupivacaine followed by saline. In: Bonica JJ, AlbeFesard D (eds). Advances in pain research and therapy. Vol. 1. Raven Press, New York, 1976, pp 927-932.

210. Bush K, Hillier S. A controlled study of caudal epidural injections of triamcinolone plus procaine for the management of intractable sciatica. Spine 1991; 16:572-575.

211. Mathews JA, Mills SB, Jenkins VM, Grimes SM, Morkel MJ, Mathews W, Scott CM, Sittampalam Y. Back pain and sciatica: controlled trials of manipulation, traction, sclerosant and epidural injections. Brit / Rheumatol 1987; 26:416-423.

212. Beliveau P. A comparison between epidural anesthesia with and without corticosteroids in the treatment of sciatica. Rheum Phys Med 1971; 11:40-43.

213. Blankenbaker DG, De Smet AA, Stanczak JD, Fine JP. Lumbar radiculopathy: treatment with selective lumbar nerve blocks: comparison of effectiveness of triamcinolone and betamethasone injectable suspensions. Radiology 2005; 237:738-741.

214. Helsa PE, Breivik H. Epidural analgesia and epidural steroid injection for treatment of chronic low back pain and sciatica. Tidsskr Nor Laegeforen 1979; 99:936-939.

215. Revel M, Auleley GR, Alaoui S, Nguyen M, Duruoz T, Eck-Michaud S, Roux C, Amor B. Forceful epidural injections for the treatment of lumbosciatic pain with post-operative lumbar spinal fibrosis. Rev Rhum Engl Ed 1996; 63:270-277.

216. Meadeb J, Rozenberg S, Duquesnoy B, Kuntz JL, Le Loet X, Sebert JL, Le Goff $P$, Fallut M, Marty M, Blevin S, Guggenbuhl P, Chales G, Duvauferrier R. Forceful sacrococcygeal injections in the treatment of postdiscectomy sciatica. A controlled study versus glucocorticoid injections. Joint Bone Spine 2001; 68:43-49.

217. Manchikanti L, Pampati V, Rivera JJ, Beyer CD, Damron KS, Barnhill RC. Caudal epidural injections with sarapin steroids in chronic low back pain. Pain Physician 2001; 4:322-335.

218. Manchikanti L., Singh V, Rivera JJ, Pampati V, Beyer CD, Damron KS, Barnhill
RC. Effectiveness of caudal epidural injections in discogram positive and negative chronic low back pain. Pain Physician 2002; 5:18-29.

219. Yates DW. A comparison of the types of epidural injection commonly used in the treatment of low back pain and sciatica. Rheum Rehab 1978; 17:181-186.

220. Waldman SD. The caudal epidural administration of steroids in combination with local anesthetics in the palliation of pain secondary to radiographically documented lumbar herniated disc: a prospective outcome study with 6-months follow-up. Pain Clinic 1998; 11:43-49.

221. Ciocon JO, Galindo-Ciocon D, Amaranath L, Galindo D. Caudal epidural blocks for elderly patients with lumbar canal stenosis. J Am Geriatr Soc 1994; 42:593-596.

222. Barré L, Lutz GE, Southern D, and Cooper G. Fluoroscopically Guided Caudal Epidural Steroid Injections for Lumbar Spinal Stenosis: a restrospective evaluation of long term efficacy. Pain Physician 2004; 7:187-193.

223. Hauswirth R, Michot F. Caudal epidural injection in the treatment of low back pain. Ischweizerische Medizinische Wochenschrift 1982; 112:222-225.

224. Goebert HW Jr, Jallo SJ, Gardner WJ, Wasmuth CE. Painful radiculopathy treated with epidural injections of procaine and hydrocortisone acetate: results in 113 patients. Anesth Analg 1961; 140:130-134.

225. Botwin KP, Gruber RD, Bouchlas CG, Torres-Ramos FM, Freeman TL, Slaten WK. Complications of fluoroscopically guided transforaminal lumbar epidural injections. Arch Phys Med Rehabil 2000; 81:1045-1050.

226. Botwin KP, Castellanos R, Rao S, Hanna AF, Torres-Ramos FM, Gruber RD, Bouchlas CG, Fuoco GS. Complications of fluoroscopically guided interlaminar cervical epidural injections. Arch Phys Med Rehabil 2003; 84:627-633.

227. Botwin KP, Baskin M, and Rao S. Adverse effects of fluoroscopically guided interlaminar thoracic epidural steroid injections. Am J Phys Med Rehabil 2006; 85:14-23.

228. Botwin KP, Gruber RD, Bouchlas CG, Torres-Ramos FM, Hanna A, Rittenberg J, Thomas SA. Complications of fluoroscopically guided caudal epidural injections. Arch Phys Med Rehabil 2001; 80:416-424.

229. Furman MB, O’Brien EM, Zgleszewski TM. Incidence of intravascular penetration in transforaminal lumbosacral epi- 
dural steroid injections. Spine 2000; 25:2628-2632.

230. Furman MB, Giovanniello MT, O’Brien $E M$. Incidence of intravascular penetration in transforaminal cervical epidural steroid injections. Spine 2003; 28:2125.

231. Manchikanti L, Cash KA, Pampati V, Damron KS, McManus CD. Evaluation of lumbar transforaminal epidural injections with needle placement and contrast flow patterns: a prospective, descriptive report. Pain Physician 2004; 7:217-224.

232. Manchikanti L, Bakhit CE, Pampati V. The role of epidurography in caudal neuroplasty. Pain Digest 1998; 8:277281.234.

233. Manchikanti L, Cash KA, Pampati V, McManus CD, Damron KS. Evaluation of fluoroscopically guided caudal epidural injections. Pain Physician 2004; 7:81-92.

234. Derby R, Lee SH, Kim BJ, Chen Y, and Seo KS. Complications following cervical epidural steroid injections by expert interventionalists in 2003. Pain Physician 2004; 7:445-449.

235. Beckman WA, Mendez RJ, Paine GF, Mazzilli MA. Cerebellar herniation after cervical transforaminal epidural injection. Reg Anesth Pain Med 2006; 31:282-285.

236. Ludwig MA and Burns SP. Spinal cord infarction following cervical transforaminal epidural injection: a case report. Spine 2005; 30:E266-E268.

237. Rozin L, Rozin R, Koehler SA, Shakir A, Ladham S, Barmada M, Dominick J, Wecht $\mathrm{CH}$. Death during transforaminal epidural steroid nerve root block $\left(\mathrm{C}_{7}\right)$ due to perforation of the left vertebral artery. Am J Forensic Med Pathol 2003; 24:351-355.

238. Houten JK, Errico TJ. Paraplegia after lumbosacral nerve root block: report of three cases. Spine J 2002; 2:70-75.

239. Cousins MJ. An additional dimension to the efficacy of epidural steroids. Anesthesiology 2000; 93:565.

240. Brouwers PJ, Kottink EJ, Simon MA, Prevo RL. A cervical anterior spinal artery syndrome after diagnostic blockade of the right C6-nerve root. Pain 2001; 91:397-399.

241. Nash TP. Comment on A cervical anterior spinal artery syndrome after diagnostic blockade of the right C6-nerve root. Pain 2002; 91:217-218.

242. Karasek M and Bogduk N. Temporary neurologic deficit after cervical transforaminal injection of local anesthetic.
Pain Med 2004; 5:202-205.

243. Huntoon MA. Anatomy of the cervical intervertebral foramina: vulnerable arteries and ischemic neurologic injuries after transforaminal epidural injections. Pain 2005; 117:104-111.

244. Ma DJ, Gilula LA, Riew KD. Complications of fluoroscopically guided extraforaminal cervical nerve blocks: an analysis of 1036 injections. J Bone Joint Surg Am 2005; 87:1025-1030.

245. Glaser SE and Falco F. Paraplegia following a thoracolumbar transforaminal epidural steroid injection. Pain Physician 2005; 8:309-314.

246. Huston CW, Slipman CW, Garvin C. Complications and side effects of cervical and lumbosacral selective nerve root injections. Arch Phys Med Rehabil 2005; 86:277-283.

247. Tiso RL, Cutler T, Catania JA, Whalen $K$. Adverse central nervous system sequelae after selective transforaminal block: the role of corticosteroids. Spine J 2004; 4:468-474.

248. Quintero N, Laffont I, Bouhmidi L, Rech C, Schneider AE, Garvardin T, Dizien 0. Transforaminal epidural steroid injection and paraplegia: case report and bibliographic review. Ann Readapt Med Phys 2006; 49:242-247.

249. Bose B. Quadriparesis following cervical epidural steroid injections: case report and review of the literature. Spine J 2005; 5:558-563.

250. Huntoon MA, Martin DP. Paralysis after transforaminal epidural injection and previous spinal surgery. Reg Anesth Pain Med 2004; 29:494-495.

251. Bilir A, Gulec S. Cauda equina syndrome after epidural steroid injection: a case report. I Manipulative Physiol Ther 2006; 29:492-494.

252. Tripathi M, Nath SS, Gupta RK. Paraplegia after intracord injection during attempted epidural steroid injection in an awake-patient. Anesth Analg 2005; 100:1209-1211.

253. Reitman CA, Watters W. Subdural hematoma after cervical epidural steroid injection. Spine 2002; 27:E174-E176.

254. Ziai WC, Ardelt AA, Llinas RH. Brainstem stroke following uncomplicated cervical epidural steroid injection. Arch Neurol 2006; 63:1643-1646.

255. Bromage RP, Benumof JL. Paraplegia following intracord injection during attempted epidural anesthesia under general anesthesia. Reg Anesth Pain Med 1998; 23:104-107.

256. Hodges SD, Castleberg RL, Miller T, Ward R, Thornburg C. Cervical epidur- al steroid injection with intrinsic spinal cord damage: two case reports. Spine 1998; 23:2137-2142.

257. Williams KN, Jackowski A, Evans PJ. Epidural hematoma requiring surgical decompression following repeated cervical epidural steroid injections for chronic pain. Pain 1990; 42:197-199.

258. Dietrich CL, Smith CE. Epidural granuloma and intracranial hypotension resulting from cervical epidural steroid injection. Anesthesiology 2004; 100:445-447.

259. Saigal G, Donovan PMJ, Kozic D. Thoracic intradural Aspergillus abscess formation following epidural steroid injection. Am J Neuroradiol 2004; 25:642-644.

260. Waldman SD. Cervical epidural abscess after cervical epidural nerve block with steroids (Letter). Anesth Anal 1991; 72:717.

261. Mamourian AC, Dickman CA, Drayer BP, Sonntag VK. Spinal epidural abscess: three cases following spinal epidural injection demonstrated with magnetic resonance imaging. Anesthesiology 1993; 78:204-207.

262. Knight JW, Cordingley JJ, Palazzo MG. Epidural abscess following epidural steroid and local anesthetic injection. Anaesthesia 1997; 52:576-578.

263. Kaul S, Meena AK, Sundaram C, Reddy JM, Naik RT, Murthy JM. Spinal extradural abscess following local steroid injection. Neurol India 2000; 48:181-183.

264. Sabel M, Felsberg J, Neuen-Jacob E, Lichota A, Schnitzler A, Herdmann J. Enlargement of a chronic aseptic lumbar epidural abscess by intraspinal injections - a rare cause of progressive paraparesis. Zentralbl Neurochir 2000; 61:111-114.

265. Huang RC, Shapiro GS, Lim M, Sandhu HS, Lutz GE, Herzog RJ. Cervical epidural abscess after epidural steroid injection. Spine 2004; 29:E7-E9.

266. Parlier-Cuau C, Carlier RY, David P, Silva M, Doyon D. Subdural abscess. Rare complication of epidural infiltration: apropos of a case and review of the literature. J Radiol 1993; 74:205-209.

267. Hooten WM, Mizerak A, Carns PE. Discitis after lumbar epidural corticosteroid injection: a case report and analysis of the case report literature. Pain Med 2006; 7:46-51.

268. Finn KP and Case JL. Disk entry: a complication of transforaminal epidural injection--a case report. Arch Phys Med Rehabil 2005; 86:1489-1491.

269. Huang J, Kwa A. Lumbar discogram resulting from lumbar interlaminar epi- 
dural injection. J Clin Anesth 2004; 16:296-298.

270. Kabbara AK, Rosenberg SK, and Untal C. Methecillin-resistant staphyloccus aureus epidural abscess after transforaminal epidural steroid injection. Pain Physician 2004; 7:269-272.

271. Hooten WM, Kinney MO, Huntoon MA. Epidural abscess and meningitis after epidural corticosteroid injection. Mayo Clin Proc 2004; 79:682-686.

272. Yue WM, Tan SB. Distant skip level discitis and vertebral osteomyelitis after caudal epidural injection: $s$ case report of a rare complication of epidural injections. Spine 2003; 28:E209-E211.

273. Simopoulos T, Peeters-Asdourian C. Pneumocephalus after cervical epidural steroid injection. Anesth \& Anal 2001; 92:1576-1577.

274. Nishimura H, Uemura Y, Fukuda S, Kamada Y, Moriwaki T. Two cases of pyogenic cervical discitis presenting tetraparesis. No Shinkei Geka 2000; 28:631637.

275. Hawley JS, J. P. Ney, and M. M. Swanberg. Subarachnoid pneumocephalus from epidural steroid injection. Headache 2005; 45:247-248.

276. Young WF. Transient blindness after lumbar epidural steroid injection: a case report and literature review. Spine 2002; 27:E476-E477.

277. Browning DJ. Acute retinal necrosis following epidural steroid injections. Am J Ophthalmol 2003; 136:192-194.

278. Iida T, Spaide RF, Negrao SG, Carvalho CA, and Yannuzzi LA. Central serous chorioretinopathy after epidural corticosteroid injection. Am J Ophthalmol 2001; 132:423-425.

279. Pizzimenti JJ, Daniel KP. Central serous chorioretinopathy after epidural steroids. Pharmacotherapy 2005; 25:11411146.

280. McAllister RK, McDavid AJ, Meyer TA, Bittenbinder TM. Recurrent persistent hiccups after epidural steroid injection and analgesia with bupivacaine. Anesth Analg 2005; 100:1834-1836.

281. Slipman CW, Chow DW, Lenrow DA, Blaugrund JE, and Chou LH. Dysphonia associated with epidural steroid injection: a case report. Arch Phys Med Rehabil 2002; 83:1309-1310.

282. Everett CR, Baskin MN, Novoseletsky
D, Speach D, and Patel R. Flushing as a side effect following lumbar transforaminal epidural steroid injection. Pain Physician 2004; 7:427-429.

283. MacLean CA, Bachman DT. Documented arterial gas embolism after spinal epidural injection. Ann Emerg Med 2001; 38:592-595.

284. McMillan MR, Crumpton C. Cortical blindness and neurologic injury complicating cervical transforaminal injection for cervical radiculopathy. Anesthesiology 2003; 99:509-511.

285. Mateo E, Lopez-Alarcon MD, Moliner S, Calabuig E, Vivo M, De Andres J, Grau F. Epidural and subarachnoid pneumocephalus after epidural technique. Eur J Anesthesiol 1999; 16:413-417.

286. Katz JA, Lukin R, Bridenbaugh PO, Gunzenhauser L. Subdural intracranial air: an unusual cause of headache after epidural steroid injection. Anesthesiology 1991; 74:615-618.

287. Gutknecht DR. Chemical meningitis following epidural injections of corticosteroids (Letter). Am J Med 1987; 82:570.

288. Kusher FH, Olson JC. Retinal hemorrhage as a consequence of epidural steroid injection. Arch Opthalmol 1995; 113:309-313.

289. Elias M. A rare cause of radiculopathy following transforaminal epidural steroid injection. Pain Clinic 1998; 11:159160.

290. Stohr M, Mayer K. Nerve-root damage from local injections. Dtsch Med Wochenschr 1976; 101:1218-1220.

291. Milhaud D, Heroum C, Charif M, Saulnier P, Pages M, Blard JM. Dural puncture and corticotherapy as risks factors for cerebral venous sinus thrombosis. Eur J Neruol 2000; 7:123-124.

292. Nelson DA, Landau WM. Intraspinal steroids: history, efficacy, accidentality, and controversy with review of United States Food and Drug Administration reports. J Neurol Neurosurg Psychiatry 2001; 70:433-443.

293. Manchikanti L. Role of neuraxial steroids in interventional pain management. Pain Physician 2002; 5:182-199.

294. Delaney TJ, Rowlingson JC, Carron H, Butler A. Epidural steroid effects on nerves and meninges. Anesth Analg 1980; 58:610-614.

295. MacKinnon Se, Hudson AR, Gentilli R.
Peripheral nerve injection injury with steroid agents. Plast Reconstr Surg 1982; 69:482-489.

296. Chino N, Awad EA, Kottke FJ. Pathology of propylene glycol administered by perineural and intramuscular injection in rats. Arch Phys Med Rehab 1974; 55:33-38.

297. Benzon HT, Gissen AJ, Strichartz GR, Avram MJ, Covino BG. The effect of polyethylene glycol on mammalian nerve impulses. Anesth Analg 1987; 66:553-559.

298. Abram SE, Marsala M, Yaksh TL. Analgesic and neurotoxic effects of intrathecal corticosteroids in rats. Anesthesiology 1994; 81:1198-1205.

299. Latham JM, Fraser RD, Moore RJ, Blumbergs PC, Bogduk N. The pathologic effects of intrathecal betamethasone. Spine 1997; 22:1558-1562.

300. Robustelli della Cuna FS, Mella M, Magistrali G, Ricci M, Losurdo A, Goglio AM. Stability and compatibility of methylprednisolone acetate and ropivacaine hydrochloride in polypropylene syringes for epidural administration. Am J Health Syst Pharm 2001; 58:1753-1756.

301. Manchikanti L, Pampati V, Beyer CD, Damron KS, Cash KA, Moss TL. The effect of neuraxial steroids on weight and bone mass density: a prospective evaluation. Pain Physician 2000; 3:357-366.

302. Manchikanti L, Cash KA, Moss TL, Pampati V. Effectiveness of protective measures in reducing risk of radiation exposure in interventional pain management: a prospective evaluation. Pain Physician 2003; 6:301-305.

303. Manchikanti L, Cash KA, Moss TL, Rivera JJ, Pampati V. Risk of whole body radiation exposure and protective measures in fluoroscopically guided interventional techniques: a prospective evaluation. BMC Anesthesiol 2003; 3:2.

304. Manchikanti L, Cash KA, Moss TL, Pampati V. Radiation exposure to the physician in interventional pain management. Pain Physician 2002; 5:385-393.

305. Hopayiank K, Mugford M. Conflicting conclusions from two systematic reviews of epidural steroid injections for sciatica: which evidence should general practitioners heed? Br J Gen Pract 1999; 49:57-60. 